\title{
30. SYNTHESIS OF BIOSTRATIGRAPHY, CENTRAL EQUATORIAL PACIFIC, DEEP SEA DRILLING PROJECT LEG 85: REFINEMENT OF OLIGOCENE TO QUATERNARY BIOCHRONOLOGY ${ }^{1}$
}

\author{
John A. Barron, U.S. Geological Survey, Menlo Park \\ Catherine A. Nigrini, Scripps Institution of Oceanography \\ Annick Pujos, Université de Bordeaux \\ Tsunemasa Saito, Yamagata University \\ Fritz Theyer, Hawaii Institute of Geophysics \\ Ellen Thomas, Scripps Institution of Oceanography \\ and \\ Norbert Weinreich, Institut für Geophysik, Ruhr Universität Bochum²
}

\begin{abstract}
Biostratigraphic studies using planktonic and benthic foraminifers, calcareous nannofossils, radiolarians, diatoms, and silicoflagellates are summarized for the four main sequences (Sites 572 to 575) collected during DSDP Leg 85 in the central equatorial Pacific. Upper Eocene through Quaternary reference sections were recovered at Sites 573 and 574, and middle Miocene through Quaternary and lower Miocene through Quaternary reference sections were cored at Sites 572 and 575 , respectively. Detailed graphic correlation plots suggest that Site 573 may contain as many as nine short hiatuses. Site 572 in the fertile eastern equatorial Pacific is apparently free of hiatuses, and Sites 574 and 575 have hiatuses (two each) only in the compressed upper sections.

Few inconsistencies exist in the various microfossil stratigraphies. Diachronous species occurrences are identified, and age estimates for 66 late Eocene through Quaternary microfossil datums have been extrapolated from age-vs.-depth plots constructed from 63 datums with direct and/or indirect ties to paleomagnetic stratigraphy.

An addendum presents an alternative biostratigraphic time scale for the middle and late Miocene based on a correlation of paleomagnetic Anomaly 5 with paleomagnetic Chron 11.
\end{abstract}

\section{INTRODUCTION}

Upwelling associated with the equatorial current system renews the supply of nutrients to the surface waters along the equator in the central Pacific and creates one of the Earth's most fertile planktonic belts. Production rates of both biogenic carbonate (planktonic foraminifers and calcareous nannofossils) and silica (diatoms and radiolarians) are high in this equatorial belt, which has a present-day width of 3 to $4^{\circ}$ and a maximum expression in the sediment slightly offset to the north of the equator. Siliceous microfossils (mostly diatoms) are dominant in sediment east of $120^{\circ} \mathrm{W}$, whereas carbonate microfossils become increasingly more abundant to the west. Spreading and rotation of the ocean crust away from the East Pacific Rise has resulted in a northwestward displacement of this equatorial Pacific sediment bulge.

The central equatorial Pacific has received considerable attention for biostratigraphic and paleoceanographic studies in recent years (van Andel et al., 1975; Leinen, 1979; Savin et al., 1981; Keller and Barron, 1983). DSDP

\footnotetext{
${ }^{\prime}$ Mayer, L., Theyer, F., et al., Init. Repts. DSDP, 85: Washington (U.S. Govt. Printing Office).

${ }_{2}^{2}$ Addresses: (Barron) U.S. Geological Survey, Menlo Park, CA 94025; (Nigrini, present address) 510 Papyrus Dr., La Habra Heights, CA 90631; (Pujos) Université de Bordeaux, 33405 Talence, France; (Saito) Yamagata University, Yamagata 990, Japan; (Theyer, present address) University of Southern California, Los Angeles, CA 90089; (Thomas, present address) Lamont-Doherty Geological Observatory, Columbia University, Palisades, NY 10964; (Weinreich) Institut für Geophysik, Ruhr-Universität Bochum, Bochum, Federal Republic of Germany.
}

Site 77 has been thoroughly studied for planktonic foraminifers (Jenkins and Orr, 1972; Keller, 1980, 1981, 1983a), calcareous nannofossils (Bukry, 1972; Gartner, 1972; Lohmann and Carlson, 1981), radiolarians (Goll, 1972, 1979; Westberg and Riedel, 1978), and diatoms (Milow in Hays et al., 1972; Keller et al., 1982; Barron, 1981, 1983; Harwood, 1982). Site 77 has undoubtedly been the most important reference section for establishing microfossil datum sequences for the low-latitude $\mathrm{Pa}$ cific and for correlating planktonic microfossil stratigraphies. Site 77 has also been well researched for benthic and planktonic foraminiferal isotopes (Haq et al., 1980; Savin et al., 1981; Keigwin and Keller, 1984).

A primary purpose of DSDP Leg 85 was to complete hydraulic piston coring in this high-productivity area of the central equatorial Pacific. Recovery of relatively undisturbed cores in sediment with moderate to high ( $>15$ $\mathrm{m} / \mathrm{m}$.y.) accumulation rates would allow high-resolution stratigraphic and isotope studies to be extended back in time at least as far as the early Miocene. Such high-resolution studies are needed not only to refine the resolution of Cenozoic time; they are also crucial for understanding the mechanisms and sequencing of paleoceanographic and paleoclimatic changes (e.g., Keller and Barron, 1983; Vincent and Killingley, this volume).

Five sites were occupied during Leg 85 (Sites 571 to 575) (Fig. 1). Sites 571 and 572 lie near the eastern edge of the equatorial sediment bulge; Sites 573 to 575 form a south-to-north transect $\left(0^{\circ} \mathrm{N}\right.$ to $\left.6^{\circ} \mathrm{N}\right)$ at about $133^{\circ} \mathrm{W}$, 


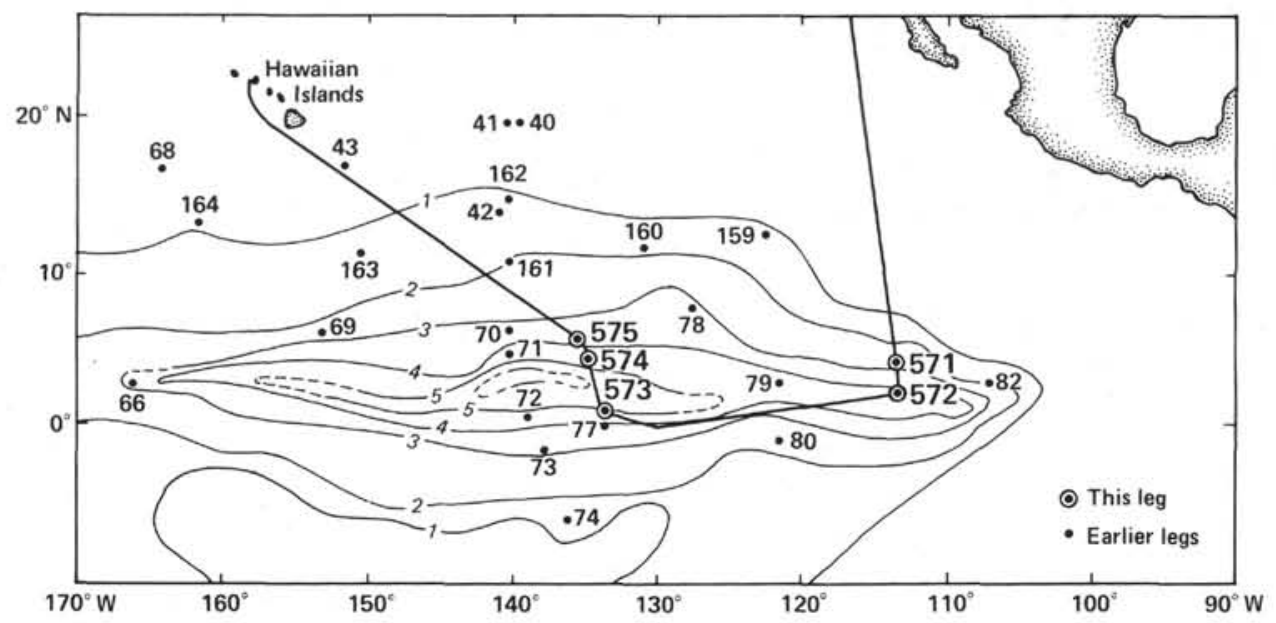

Figure 1. Cruise track and site locations of DSDP Leg 85 in relation to acoustic sediment thickness (contours in tenths of seconds of two-way traveltime) and previously drilled DSDP holes in the central equatorial Pacific.

near the center of the bulge. Seventeen holes, the majority of which were completed with hydraulic piston coring, were drilled at the five sites (Table 1).

\section{BIOSTRATIGRAPHIC TIME SCALE}

The biostratigraphic time scale adopted for Leg 85 (Fig. 2) incorporates the planktonic foraminiferal zones of Blow (1969) and Berggren (1969) (with some modification by Saito, this volume); the calcareous nannofossil zones of Bukry (1975), with notation after Okada and Bukry (1980); the radiolarian zones of Nigrini (1971) and Riedel and Sanfilippo (1978); and the diatom zones of Burckle (1972) and Barron (1983, in press, and this volume). The silicoflagellate zones of Bukry $(1981,1983)$ have also been included on the time scale on the basis of their correlation with other microfossil zones in Leg 85 material.

The paleomagnetic time scale utilized is that of Berggren, Kent, and Flynn (in press) and Berggren, Kent, and Van Couvering (in press), and the paleomagnetic chrons are recognized in the manner of LaBrecque et al. (1977) and Tauxe et al. (1983). See also the Addendum to this chapter.

Correlation of the Eocene and Oligocene zones with paleomagnetic stratigraphy follows Poore et al. (1983) and Berggren, Kent, and Flynn (in press), for the most part. Radiolarian zonal boundaries have been shifted somewhat, on the basis of Leg 85 results (Nigrini, this volume). Correlation of the CP17/CP18 calcareous nannofossil zone boundary with the upper part of the reversed event of paleomagnetic Chron $\mathrm{C} 12$ at about 33.3 $\mathrm{Ma}$ (Lowrie et al., 1982) is accepted in preference to correlation of that datum lower in Chron $\mathrm{C} 12$ at about 34.1 $\mathrm{Ma}$ (Berggren, Kent, and Flynn, in press), because it is more consistent with Leg 85 planktonic foraminiferal and radiolarian stratigraphy (see section on age-vs.-depth plots).

The Miocene correlations of biozones with paleomagnetic stratigraphy are after Barron et al. (in press), and include new direct paleomagnetic correlations for paleo-

Table 1. Summary of locations, coring records, and oldest sediments cored, DSDP Leg 85 holes.

\begin{tabular}{|c|c|c|c|c|c|c|c|}
\hline Hole & Latitude & Longitude & $\begin{array}{l}\text { Water } \\
\text { depth }^{a} \\
\text { (m) }\end{array}$ & $\begin{array}{l}\text { Sub-bottom } \\
\text { depth } \\
\text { range cored } \\
\text { (m) }\end{array}$ & $\begin{array}{l}\text { Number } \\
\text { of cores }\end{array}$ & $\begin{array}{l}\text { Total core } \\
\text { recovered } \\
(\mathrm{m})\end{array}$ & $\begin{array}{l}\text { Oldest } \\
\text { sediment } \\
\text { cored }\end{array}$ \\
\hline 571 & $03^{\circ} 59.84^{\prime} \mathrm{N}$ & $114^{\circ} 08.53^{\prime} \mathrm{W}$ & 3962 & $0-7.11$ & 1 & 7.11 & Pleistocene \\
\hline 572 & $01^{\circ} 26.09^{\prime} \mathrm{N}$ & $113^{\circ} 50.52^{\prime} \mathrm{W}$ & 3893 & $0-18.7$ & 2 & 9.25 & Pleistocene \\
\hline $572 \mathrm{~A}$ & $01^{\circ} 26.09^{\prime} \mathrm{N}$ & $113^{\circ} 50.52^{\prime} \mathrm{W}$ & 3893 & $0-154$ & 17 & 154.35 & upper Miocene \\
\hline $572 \mathrm{~B}$ & $01^{\circ} 26.09^{\prime} \mathrm{N}$ & $113^{\circ} 50.52^{\prime} \mathrm{W}$ & 3893 & $154-169.4$ & 4 & 19.95 & upper Miocene \\
\hline $572 \mathrm{C}$ & $01^{\circ} 26.09^{\prime} \mathrm{N}$ & $113^{\circ} 50.52^{\prime} \mathrm{W}$ & 3893 & $0-169.5$ & 20 & 161.56 & upper Miocene \\
\hline 572D & $01^{\circ} 26.09^{\prime} \mathrm{N}$ & $113^{\circ} 50.52^{\prime} \mathrm{W}$ & 3893 & $151-489.0$ & 34 & 258.87 & middle Miocene \\
\hline 573 & $00^{\circ} 29.91^{\prime} \mathrm{N}$ & $133^{\circ} 18.57^{\prime} \mathrm{W}$ & 4301 & $0-158.6$ & 19 & 159.4 & upper Miocene \\
\hline $573 \mathrm{~A}$ & $00^{\circ} 29.91^{\prime} \mathrm{N}$ & $133^{\circ} 18.57^{\prime} \mathrm{W}$ & 4301 & $14.0-57.7$ & 6 & 53.5 & lower Pliocene \\
\hline $573 B$ & $00^{\circ} 29.91^{\prime} \mathrm{N}$ & $133^{\circ} 18.57^{\prime} \mathrm{W}$ & 4301 & $138.5-529.0$ & 43 & 279.7 & upper Eocene \\
\hline 574 & $04^{\circ} 12.52^{\prime} \mathrm{N}$ & $133^{\circ} 19.81^{\prime} \mathrm{W}$ & 4561 & $0-206.5$ & 31 & 208.93 & lower Miocene \\
\hline $574 \mathrm{~A}$ & $04^{\circ} 12.52^{\prime} \mathrm{N}$ & $133^{\circ} 19.81^{\prime} \mathrm{W}$ & 4561 & $6.0-186.2$ & 23 & 180.74 & lower Miocene \\
\hline $574 \mathrm{~B}$ & $04^{\circ} 12.52^{\prime} \mathrm{N}$ & $133^{\circ} 19.81^{\prime} \mathrm{W}$ & 4561 & $185.0-194.0$ & 1 & 9.45 & lower Miocene \\
\hline $574 C$ & $04^{\circ} 12.53^{\prime} \mathrm{N}$ & $133^{\circ} 19.81^{\prime} \mathrm{W}$ & 4561 & $194.5-532.5$ & 37 & 197.35 & upper Eocene \\
\hline 575 & $05^{\circ} 51.00^{\prime} \mathrm{N}$ & $135^{\circ} 02.16^{\prime} \mathrm{W}$ & 4536 & $0-98.6$ & 11 & 99.35 & lower Miocene \\
\hline $575 \mathrm{~A}$ & $05^{\circ} 51.00^{\prime} \mathrm{N}$ & $135^{\circ} 02.16^{\prime} \mathrm{W}$ & 4536 & $93.8-208.4$ & 33 & 140.53 & lower Miocene \\
\hline $575 B$ & $05^{\circ} 51.00^{\prime} \mathrm{N}$ & $135^{\circ} 02.16^{\prime} \mathrm{W}$ & 4536 & $3.3-119.0$ & 14 & 118.68 & lower Miocene \\
\hline $575 \mathrm{C}$ & $05^{\circ} 51.00^{\prime} \mathrm{N}$ & $135^{\circ} 02.16^{\prime} \mathrm{W}$ & 4536 & $0-15.8$ & 2 & 15.91 & upper Miocene \\
\hline
\end{tabular}

${ }^{\mathrm{a}}$ Water depth from sea level. 
magnetic Chrons 16 and 17 in Hole 575A, utilizing the paleomagnetic data of Weinreich and Theyer (this volume). The Pliocene and Pleistocene time scale adopted results from paleomagnetic correlations of planktonic foraminifers (Saito et al., 1975; Berggren et al., 1980), calcareous nannofossils (Gartner, 1973; Backman and Shackleton, 1983), radiolarians (Theyer et al., 1978; Labracherie, this volume), and diatoms (Burckle, 1972, 1978).

The epoch boundaries adopted in the Leg 85 biostratigraphic time scale (Fig. 2) include those of Berggren, Kent, and Flynn (in press) for the Eocene/Oligocene, early Oligocene/late Oligocene, and Oligocene/Miocene boundaries; that of Ryan et al. (1974) for the early Miocene/middle Miocene boundary; those of Berggren (1984) for the middle Miocene/late Miocene, Miocene/Pliocene, and early Pliocene/late Pliocene boundaries; and that of Berggren et al. (1980) for the Pliocene/Pleistocene boundary.

It should be noted that this biostratigraphic time scale is updated from the time scale presented in the Introduction to this volume, although most differences are minor (see Addendum for larger changes).

\section{SITE SUMMARIES}

The records of coring, biostratigraphic zonation, and paleomagnetic stratigraphy at Sites 572 to 575 are summarized on Figures 3 to 7. Only one core (of uppermost Quaternary sediment) was recovered at Site 571, because that site was occupied primarily for heat-flow studies. The base of that core (Core 571-1) contains planktonic foraminifers of Zone N23, calcareous nannofossils of Subzone CN14a, radiolarians of the Amphirhopalum ypsilon Zone, and diatoms of the Pseudoeunotia doliolus Zone, and is approximately 500,000 to 650,000 yrs. old. The reader is referred to the calcareous nannofossil chapter of Pujos ("Nannofossils from Quaternary Deposits," this volume) and the radiolarian chapter of Labracherie (this volume) for detailed stratigraphic data from Core 571-1.

\section{Site 572}

Site 572 lies within the eastern equatorial Pacific, where the permanent thermocline is relatively shallow $(>60 \mathrm{~m})$ (Wyrtki, 1966) and diatoms dominate the sediment. A complete reference section apparently free of hiatuses was recovered from the lower middle Miocene (about $15 \mathrm{Ma}$ ) through the Quaternary at the site (Fig. 3). Hydraulic piston coring extended down to the uppermost Miocene (about $170 \mathrm{~m}$ sub-bottom), and was completed in four of the five holes (Holes 572, 572A, 572B, and 572C). Uppermost Quaternary sediment was present in the single core successfully recovered from Hole 572, so Hole 572 is not included on Figure 3. Rotary coring (Hole 572D) extended from the uppermost Miocene (151.0 m sub-bottom) to the lower middle Miocene ( $464.5 \mathrm{~m}$ subbottom), and was terminated $13 \mathrm{~m}$ above the sediment/ basalt contact.

Dissolution of calcareous microfossils (especially planktonic foraminifers) is common to sporadic in the Miocene section at Site 572. A sharp downhole change from rich, well preserved planktonic foraminiferal assemblages to monotonous, moderately well preserved assemblages occurs at about $155 \mathrm{~m}$ sub-bottom (about $5.9 \mathrm{Ma}$ ). Pliocene and Quaternary planktonic foraminifers can be readily correlated with the paleomagnetically dated deepsea sequences west of Site 572 (Hays et al., 1969; Saito et al., 1975), and coiling changes in Pulleniatina are also useful for biostratigraphy (Saito, this volume).

Site 572 lies a few miles south and west of Site 81 (Fig. 1). Although the paleontologists of Leg 9 (Hays et al., 1972) assigned the basal sediments of Site 81 to planktonic foraminiferal Zone N8, basal sediments of Site 572 (Sample 572-33,CC) contain sparse specimens of Orbulina universa and are assigned to Zone N9. Radiolarians (Dorcadospyris alata Zone) and diatoms (Subzone B of the Cestodiscus peplum Zone) are consistent with this Zone N9 assignment (Fig. 3).

The sequence of microfossil zones and subzones at Site 572 is in good agreement with the Leg 85 biostratigraphic time scale (Fig. 2), except for the CN9 calcareous nannofossil zones of Pujos ("Cenozoic Nannofossils," this volume) and Gartner and Chow (this volume). The CN8/CN9 boundary has been calibrated in numerous Pacific sections with lower Zone N17, upper Didymocyrtis antepenultima Zone, and Subzone A of the Nitzschia porteri Zone by Keller et al. (1982) and Barron et al. (in press). Gartner and Chow's placement of the CN8/ CN9 boundary in Core 572D-8 agrees well with this correlation, whereas Pujos' assignment of the $\mathrm{CN} 8 / \mathrm{CN} 9$ boundary to the base of Core 572D-2 coincides with the lowermost parts of the Stichocorys peregrina and Thalassiosira convexa zones, and is more than $2 \mathrm{~m}$.y. younger (6.0 Ma vs. 8.3 Ma). Similarly, Gartner and Chow's placement of the $\mathrm{CN} 9 \mathrm{a} / \mathrm{CN} 9 \mathrm{~b}$ boundary in Core 572D-7 agrees well with the results of Keller et al. (1982) and Barron et al. (in press), who note that the $\mathrm{CN} 9 \mathrm{a} / \mathrm{CN} 9 \mathrm{~b}$ boundary (the first occurrence of the calcareous nannofossil Amaurolithus primus) almost coincides with the base of the Nitzschia miocenica Zone in the eastern equatorial Pacific (7.3 Ma). Pujos, on the other hand, places the $\mathrm{CN} 9 \mathrm{a} / \mathrm{CN} 9 \mathrm{~b}$ boundary substantially higher in Core 572A-17 (about 5.9 Ma).

Pujos' assignment of the $\mathrm{CN} 9 / \mathrm{CN} 10$ boundary, to the base of Core $572 \mathrm{~A}-13$, approximates the N18/N19 boundary $(5.2 \mathrm{Ma})$ and the Subzone B/Subzone $\mathrm{C}$ boundary of the Thalassiosira convexa Zone (5.1 Ma), a correlation noted elsewhere in the eastern equatorial Pacific by Keller et al. (1982). Gartner (1973) tied the last occurrence of Discoaster quinqueramus, the marker for the CN9/CN10 boundary, with the middle of paleomagnetic Chron 5 (about $5.5 \mathrm{Ma}$ ), but more recently Gartner et al. (1983) have argued for a correlation of this calcareous nannofossil zonal boundary with the Miocene/Pliocene boundary, or about 5.1 Ma. At Site 572, Gartner and Chow's placement of the $\mathrm{CN} 9 / \mathrm{CN} 10$ boundary in Core 572A-11 falls well into the lower Pliocene, and is certainly too high.

The Dorcadospyris alata/Diartus petterssoni zonal boundary is somewhat older at Site 572 (Fig. 3), with respect to diatoms and planktonic foraminifers, than it is in the Leg 85 biostratigraphic time scale (Fig. 2) and at 


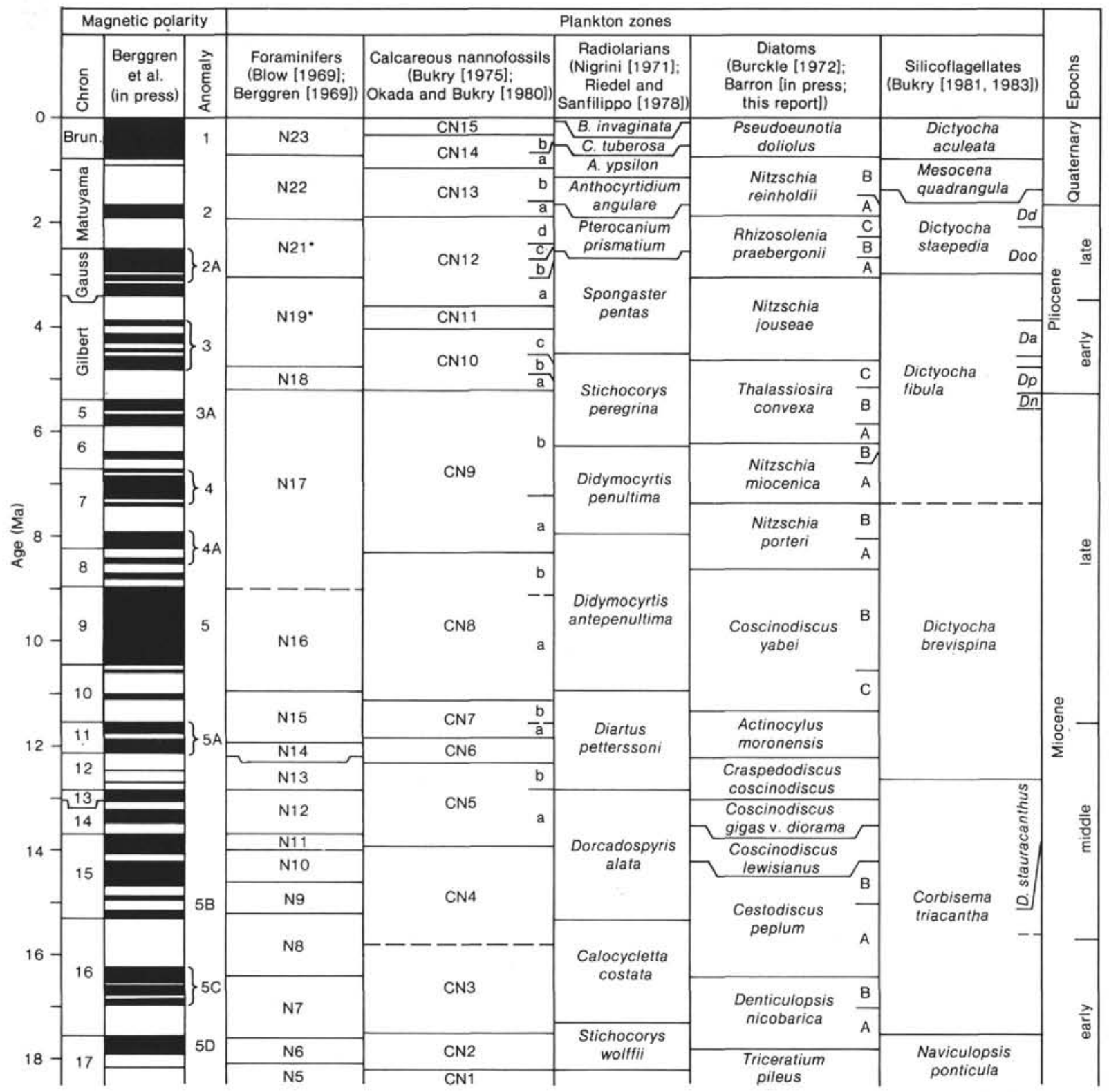




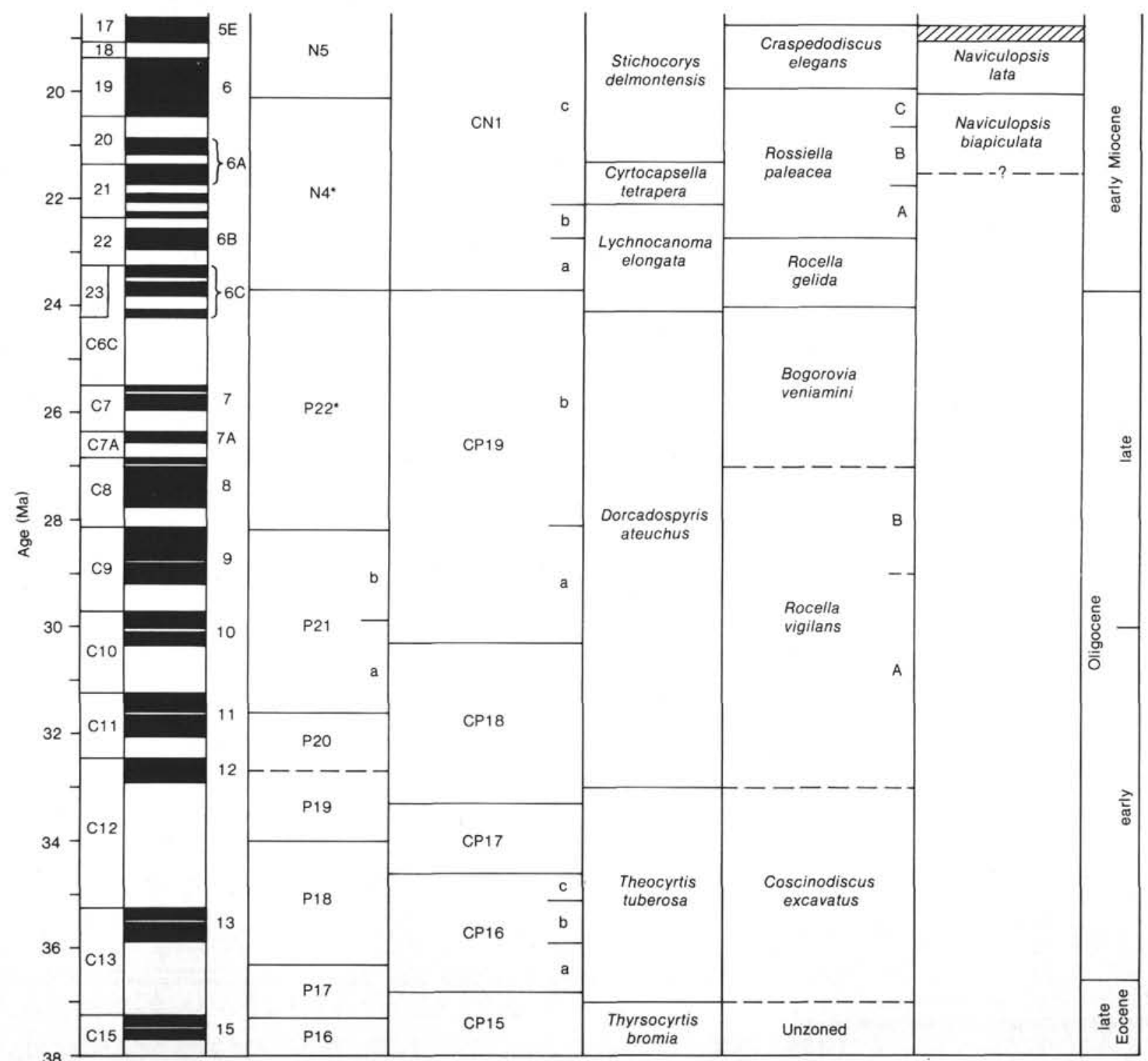

Figure 2. Biostratigraphic time scale adopted for Leg 85. Paleogene correlations mostly after Berggren, Kent, and Flynn (in press); Miocene correlations after Barron et al. (in press); and Pliocene-Pleistocene correlations synthesized from the results of Saito et al. (1975), Burckle (1972), Theyer et al. (1978), Berggren et al. (1980), and Backman and Shackleton (1983). Minor adjustments to correlations are based on Leg 85 results. Epoch boundaries follow Berggren (1984) and Berggren et al. (1980; in press), except for the early Miocene/middle Miocene boundary, which is after Ryan et al. (1974). Asterisk denotes planktonic foraminiferal zones with modified definitions (Saito, this volume). Silicoflagellate subzonal abbreviations: $D d=$ Dictyocha delicata, Doo $=D$. ornata ornata, $D a=D$. angulata, $D p=D$. pulchella, $D n=D$, neonautica. 


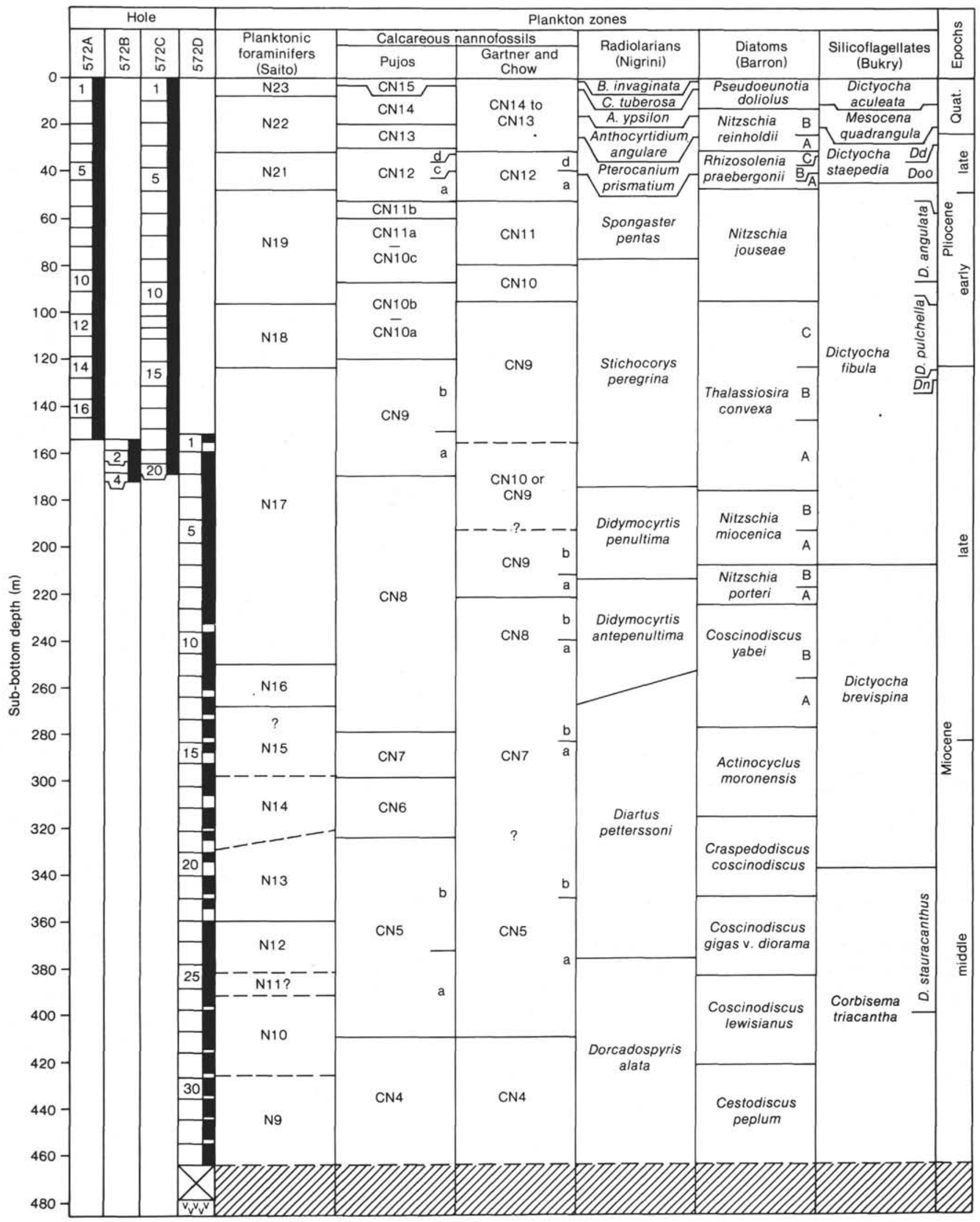

Figure 3. Coring record and biostratigraphic zonation at Site 572. Shaded intervals represent core recovery. Stratigraphy shown is for Holes $572 \mathrm{~A}$ and 572D. Refer to Nigrini (this volume) and Barron (this volume) for correlation between duplicated holes. 
both Site 574 and Site 575 . In these latter cases, the $D$. alata/D. petterssoni zonal boundary approximates the N12/N13 and Coscinodiscus gigas var. diorama/Craspedodiscus coscinodiscus zonal boundaries. At Site 572, however, the $D$. alata $/ D$. petterssoni zonal boundary falls in lower Zone N12 and lower C. gigas var. diorama Zone (Fig. 3); at Site 573 (Fig. 4), a correlation with the even older Zone N11 and Coscinodiscus lewisianus Zone is suggested.

It should also be noted that Nigrini's (this volume) placement of the Amphirhopalum ypsilon/Collosphaera tuberosa radiolarian zonal boundary in Core 572A-2 is about $6 \mathrm{~m}$ stratigraphically below Labracherie's (this volume) assignment in Core 572A-1.

\section{Site 573}

Site 573 was chosen near Site 77 , which has been the location of the most extensively studied central equatorial Pacific deep-sea section in recent years. The objective at Site 573 was to obtain an HPC section for the upper part of the Site 77 section and to core the Eocene/ Oligocene boundary. Site 573 is about $10 \mathrm{~km}(6 \mathrm{mi}$.) west of Site 77, over a sediment section about $50 \mathrm{~m}$ thicker than that at Site 77.

Upper Eocene through Quaternary sediment, typically containing well-preserved planktonic and benthic foraminifers, calcareous nannofossils, radiolarians, and diatoms, was recovered at Site 573 (Fig. 4). Virtually all of the sediment section is readily zonable by planktonic microfossils, although the thin upper Eocene section lacks both radiolarians and diatoms and part of the lower Miocene section is essentially barren of diatoms. In Hole 573 , hydraulic piston coring extended down to $158.6 \mathrm{~m}$ sub-bottom, just above the middle Miocene/upper Miocene boundary. Rotary coring in Hole 573B was completed to $529.0 \mathrm{~m}$ sub-bottom, with the sediment/basalt contact encountered at $528.0 \mathrm{~m}$ sub-bottom in upper Eocene sediments assignable to Zones P16 and CP15.

The Eocene/Oligocene boundary lies within Core 573B-42 (at approximately $525 \mathrm{~m}$ sub-bottom), in a very dark brown metalliferous claystone unit (Subunit IIIB of site chapter) relatively poor in microfossils. The stratigraphically lowest radiolarians and diatoms at Site 573 occur in Sample 573-42-1, 0-1 cm, and are assignable to the Oligocene Theocyrtis tuberosa and Coscinodiscus excavatus zones, respectively. Pujos ("Cenozoic Nannofossils," this volume) places the CP15/CP16b boundary of calcareous nannofossils between Samples 573B-42-4, $58 \mathrm{~cm}$ and 573B-42-2, $50 \mathrm{~cm}$. Planktonic foraminiferal assemblages correlated with Zone P16 occur in Sample 573B-42-4, 123-124 cm, whereas Saito (this volume) tentatively assigns Sample 573B-42-2, 5-8 cm to Oligocene Zone P18. The Eocene benthic foraminifers Nuttallides truempyi and Alabamina dissonata are present in Sample 573B-42-4, 144-147 cm, but poor preservation in the immediately overlying samples prevents accurate placement of their last-appearance datums. The sum of all the evidence suggests that a hiatus, or greatly compressed interval equivalent to Zone P17 (37.4 to $36.3 \mathrm{Ma}$ ), is present in Section 3 of Core 573B-42. A coeval hiatus at the Eocene/Oligocene boundary is present at Site 289 on the Ontong-Java Plateau in the western equatorial Pacific (Andrews et al., 1975), and is extensive in the Pacific Basin (Kennett et al., 1975).

In Hole 573, paleomagnetic stratigraphy was obtained down to the lower Gauss paleomagnetic Chron (Core 573-6); paleomagnetic stratigraphy extended down to the Cochiti event of the Gilbert Chron in Hole 573A (Weinreich and Theyer, this volume). Within the constraints of the sample intervals, correlations of the various microfossil zones with paleomagnetic stratigraphy are consistent with the Leg 85 time scale (Figs. 2, 4). The detailed studies of the Quaternary by Pujos ("Nannofossils from Quaternary Deposits," this volume, calcareous nannofossils) and Labracherie (this volume, radiolarians) show more precise calibration of microfossil events to paleomagnetic stratigraphy.

The sequence of planktonic microfossil zones (Fig. 4) encountered at Site 573 shows some inconsistencies when compared with the Leg 85 time scale (Fig. 2). The N5/ N6 and N17/N18 zonal boundaries appear to be slightly older with respect to the other microfossil zones at Site 573 . The N5/N6 boundary was correlated with paleomagnetic stratigraphy in Hole 575A, where an age of 18.1 Ma was implied, coincident with the lower part of the Stichocorys wolffii Zone of radiolarians. At Site 573 , Zone N6 appears to be longer in duration, its base correlating with the middle of the Stichocorys delmontensis Zone. Correlation of the base of N6 in Hole 574C (Fig. 5) is also with the middle of the $S$. delmontensis Zone, so it is possible that the correlation of the N5/N6 boundary with the upper normal event of paleomagnetic Chron 17, inferred from Hole 575A, is too young. Berggren (1984) indirectly correlates the N5/N6 boundary with earliest paleomagnetic Chron 17 (about 19.0 Ma), a correlation supported by correlations with radiolarian stratigraphy at Sites 573 and 574 .

In a similar manner, placement of the N17/N18 boundary in Core $573-11$ is at odds with calcareous nannofossil and diatom stratigraphies, which suggest that the Miocene/Pliocene boundary should lie in Core 573-10 (Fig. 4).

There are also a number of inconsistencies between the calcareous nannofossil stratigraphies of Pujos and Gartner and Chow at Site 573 (Fig. 4). As at Site 572, the $\mathrm{CN} 8 / \mathrm{CN} 9$ and $\mathrm{CN} 9 \mathrm{a} / \mathrm{CN} 9 \mathrm{~b}$ boundaries of Gartner and Chow are more consistent with the Leg 85 biostratigraphic time scale than are the $\mathrm{CN} 8 / \mathrm{CN} 9$ and $\mathrm{CN} 9 \mathrm{a} /$ CN9b boundaries of Pujos. It is worthwhile to note, however, that Pujos' placement of these boundaries is internally consistent with respect to the other microfossil zones at Sites 572 and 573 (Figs. 3, 4). Pujos' assignment of the CN7/CN8 boundary in Core 573B-4 is favored over Gartner and Chow's placement of that boundary in Core 573B-5, on the basis of the near coincidence of her CN7/CN8 boundary with the Actinocyclus moronensis/Coscinodiscus yabei zonal boundary of diatoms at Sites 572 (Fig. 3) and 574 (Fig. 5).

Differences in placement of the CN1/CN2 and CP18/ CP19 zonal boundaries by Pujos and by Gartner and Chow will be discussed in a later section dealing with graphic correlation plots between the sites. 


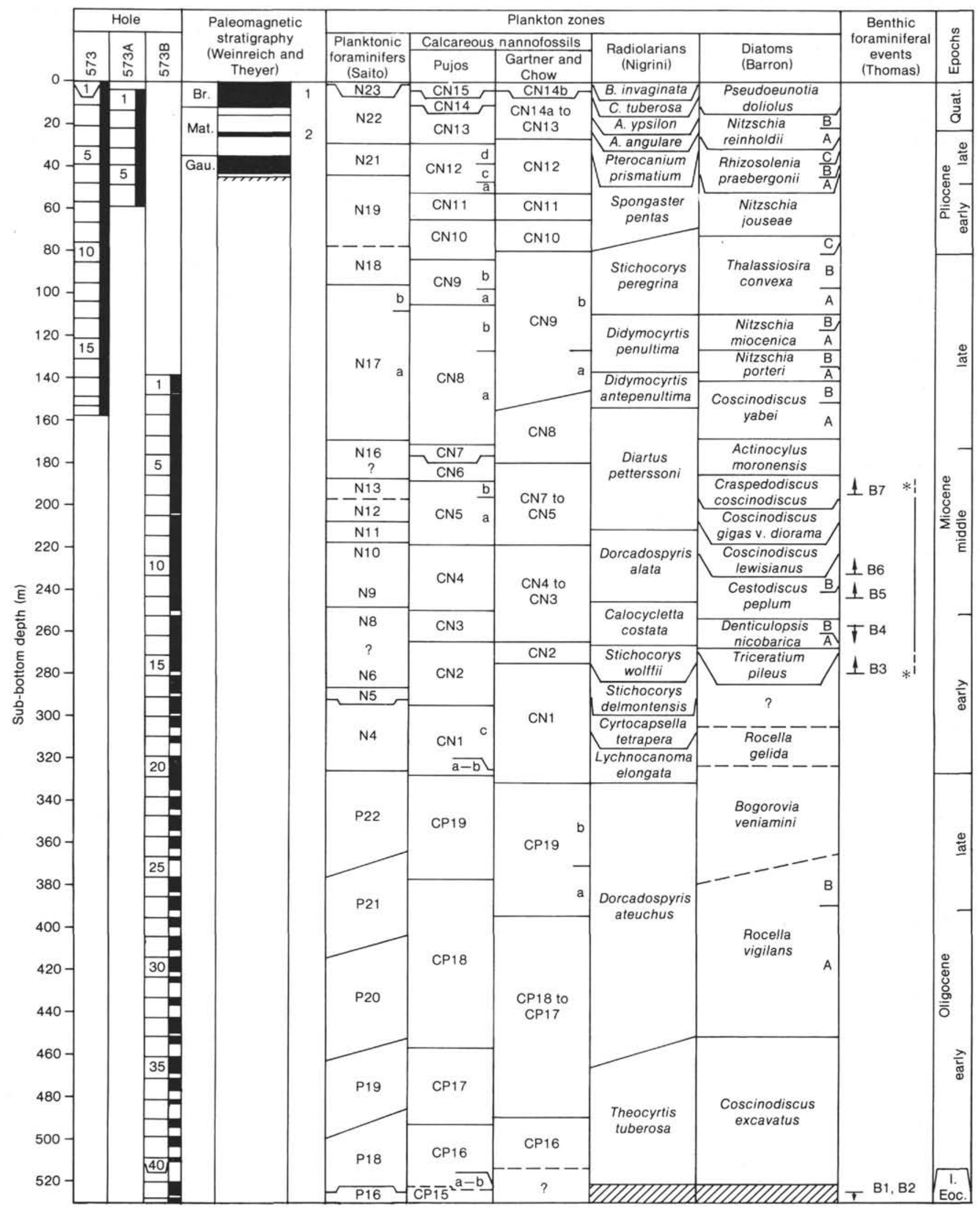

Figure 4. Coring record, biostratigraphic zonation, benthic foraminiferal events, and paleomagnetic stratigraphy at Site 573. Shaded intervals represent core recovery. Stratigraphy shown is for Holes 573 and 573B. See Nigrini (this volume), Barron (this volume), and Weinreich and Theyer (this volume) for correlation between duplicated holes. Benthic foraminiferal events are labeled on Table 6; vertical bar with asterisks represents time of maximum turnover in benthic foraminiferal assemblages. Paleomagnetic chrons are listed in left part of column, paleomagnetic anomaly numbers in right part of column. 
As discussed earlier, the Dorcadospyris alata/Diartus petterssoni radiolarian zonal boundary seems anomalously old at Site 573 with respect to the other microfossil stratigraphies, but other radiolarian zonal boundaries appear to agree reasonably well with the Leg 85 biostratigraphic time scale.

Selected benthic foraminiferal datums which show the most consistency in correlations between Sites 573, 574, and 575 (Thomas, this volume) are numbered B1 through B7 on Figures 4 to 6. Events B1 and B2, the last appearances of Alabamina dissonata and Nuttallides truem$p y i$, respectively, closely approximate the Eocene/Oligocene boundary, and have been discussed earlier. Events B3 through B7 include the first appearance of Melonis barleeanus (B3), the last appearance of Cibicidoides laurisae (B4), and the first appearances of $C$. wuellerstorf $i$ (B5), Francesita advena (B6), and Melonis pompilioides. These events took place in the late early Miocene to middle Miocene interval ( 18 to $13 \mathrm{Ma}$ ) which shows the maximum turnover in benthic foraminiferal assemblages (Thomas, this volume).

\section{Site 574}

Site 574 is the second of the three-site latitudinal transect (Sites 573 to 575 ) along $133^{\circ} \mathrm{W}$ across the equatorial Pacific high-productivity belt. Because Site 574 lies at $4^{\circ} \mathrm{N}$, north of the present-day high-biologic-productivity zone (Koblentz-Mishke et al., 1970), the Pliocene and Quaternary section is compressed relative to that at Site $573\left(0^{\circ} \mathrm{N}\right)$ (Figs. 4, 5).

The hydraulic piston coring in Hole 574 reached $206.5 \mathrm{~m}$ sub-bottom (approximately $16.7 \mathrm{Ma}$ ) and was duplicated, for the most part, by the coring in Hole 574A. Rotary coring extended from 194.5 to $532.5 \mathrm{~m}$ sub-bottom in Hole $574 \mathrm{C}$, reaching the sediment/basalt contact at $520.0 \mathrm{~m}$, in upper Eocene sediments assigned to Zones P17 and CP15.

Throughout most of the section, siliceous microfossils occur in common to high abundances and show good preservation. The abundance of diatoms declines and diatom preservation becomes poorer downhole, in the upper Oligocene to upper part of the lower Oligocene, and again downhole in Cores 574C-33 and 574C-34, near the Eocene/Oligocene boundary. Core 574C-35, the core immediately overlying the basalt, is barren of both diatoms and radiolarians. Radiolarians are generally abundant and well preserved throughout the section at Site 574.

The abundance and preservation of planktonic foraminifers fluctuates at Site 574. Parts of the lowermost Oligocene, uppermost lower Miocene, and uppermost middle Miocene show severe dissolution of planktonic foraminifers, making zonation difficult. Calcareous nannofossils, on the other hand, are typically abundant to common throughout the section.

Site 574 appears to contain an uninterrupted sequence through the Eocene/Oligocene boundary. Planktonic foraminifers suggest that the P17/P18 boundary occurs between Samples 574C-35-1, 126-128 cm and 574C-34,CC; the last occurrence of Hantkenina primitiva may, however, have been influenced by dissolution. The CP15/
CP16 calcareous nannofossil zonal boundary is placed in Core 574C-33 by Pujos, but between Cores 574C-35 and 574C-34 by Gartner and Chow (Fig. 5). The Theocyrtis tuberosa/Thyrsocyrtis bromia radiolarian zonal boundary appears to be in lower Core 574C-33, and the base of the lower Oligocene Coscinodiscus excavatus Zone of diatoms lies between Cores 574C-33 and 574C-34. The last occurrences of the Eocene benthic foraminifers Alabamina dissonata and Nuttallides truempyi (events B1 and B2, Fig. 5) are in lower Core 574C-33, in close agreement with the Eocene/Oligocene boundary (CP15/ $\mathrm{CP} 16)$ determined from calcareous nannofossils by $\mathrm{Pu}$ jos and with the Eocene/Oligocene boundary determined from radiolarians and diatoms. These data are also supported by the presence of a major increase $(0.9 \%)$ in benthic foraminiferal ${ }^{18} \mathrm{O}$ in the upper part of Core 574C-33 (between 33-1, 113-115 cm and 33-2, 113-115 $\mathrm{cm}$ ) (Miller and Thomas, this volume). Keigwin (1980) demonstrated that this shift occurs immediately above the extinction levels of Hantkenina spp. and Globorotalia cerroazulensis cerroazulensis, which mark the top of planktonic foraminiferal Zone P17.

Reworked calcareous nannofossils and diatoms are common in the uppermost part of the section (Cores 574-4 through 574-1), and reworked Oligocene planktonic foraminifers and calcareous nannofossils occur in several horizons within the lower middle Miocene at Site 574.

In general, there are few inconsistencies between the Site 574 microfossil stratigraphy (Fig. 5) and the Leg 85 biostratigraphic time scale (Fig. 2). As mentioned in the discussion of Site 573, planktonic foraminiferal Zone N6 is thicker (of longer duration) with respect to the other microfossil zones at Site 574 than it is at Site 575 (Fig. 6). Pujos' placement of the CP15/CP16, CP18/CP19, and $\mathrm{CN} 9 / \mathrm{CN} 10$ calcareous nannofossil zonal boundaries is favored over Gartner and Chow's assignments, because they are more consistent with the Leg 85 biostratigraphic time scale. As at Sites 572 and 573 (Figs. 3, 4), however, Pujos' CN8/CN9 boundary is too high, and Gartner and Chow's CN8/CN9 boundary in Core 574-7 is favored.

The radiolarian and diatom stratigraphies show no major conflicts, although coincidence of the Craspedodiscus elegans/Triceratium pileus diatom zonal boundary with the CN1/CN2 and Stichocorys delmontensis/ $S$. wolffii zonal boundaries at about $238 \mathrm{~m}$ sub-bottom (Core 574C-5) is at odds with the relationship at Site 575 (Fig. 6) and with the Leg 85 biostratigraphic time scale (Fig. 2). Barron (this volume) has suggested that a short hiatus, equivalent to hiatus NH1 of Keller and Barron (1983), is present at the $C$. elegans $/ T$. pileus boundary at Site 574.

Comparison of the stratigraphic positions of the seven benthic foraminiferal datums, B1 through B7 (see discussion of Site 573), at Site 574 (Fig. 5) and Site 573 (Fig. 4) suggests that only one, the last occurrence of $\mathrm{Ci}$ bicidoides laurisae (B4), is noticeably diachronous; it lies one calcareous nannofossil zone, one radiolarian zone, and one diatom zone lower at Site 574 than at Site 573 . The interval of maximum turnover in the benthic fora- 


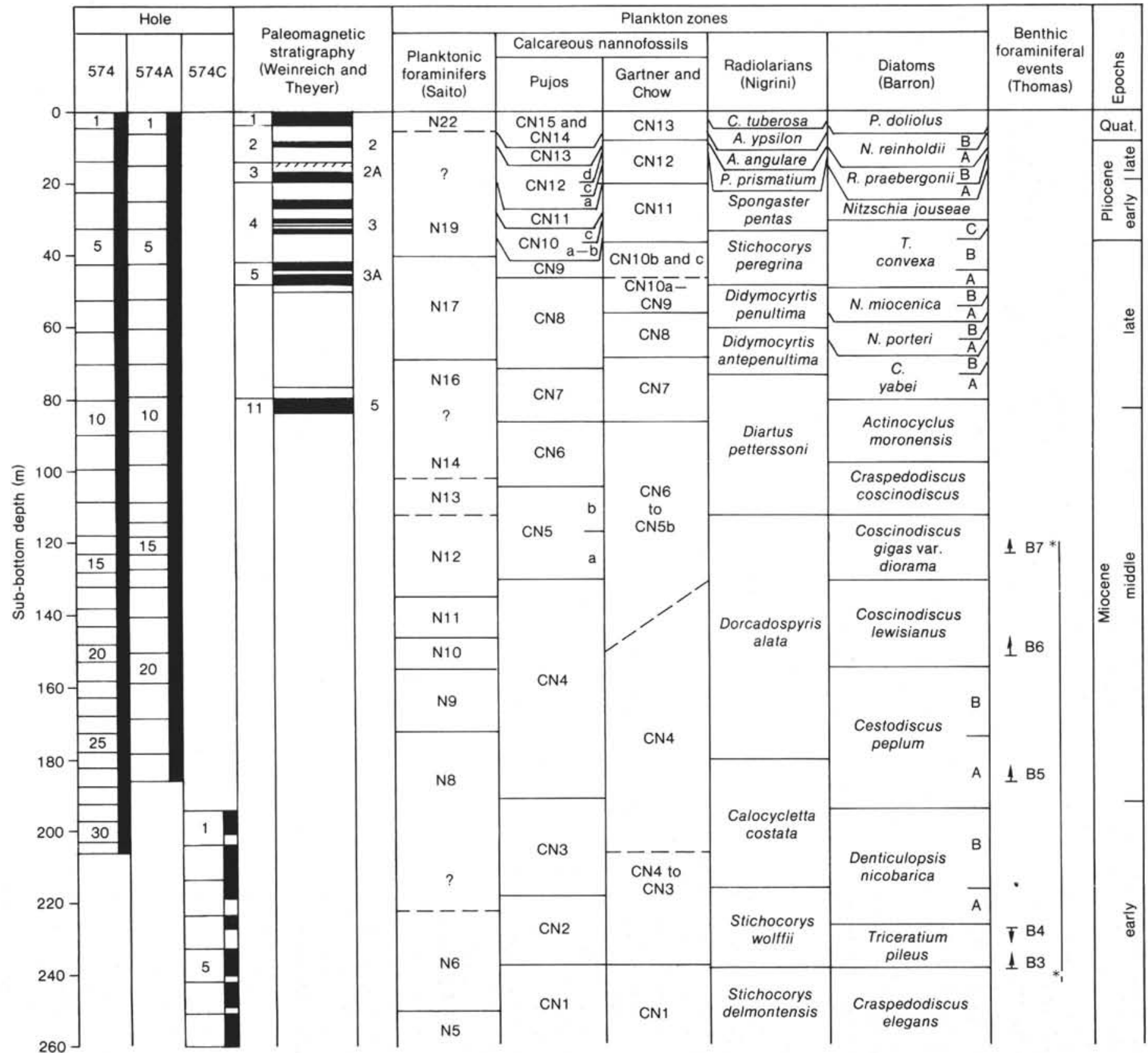




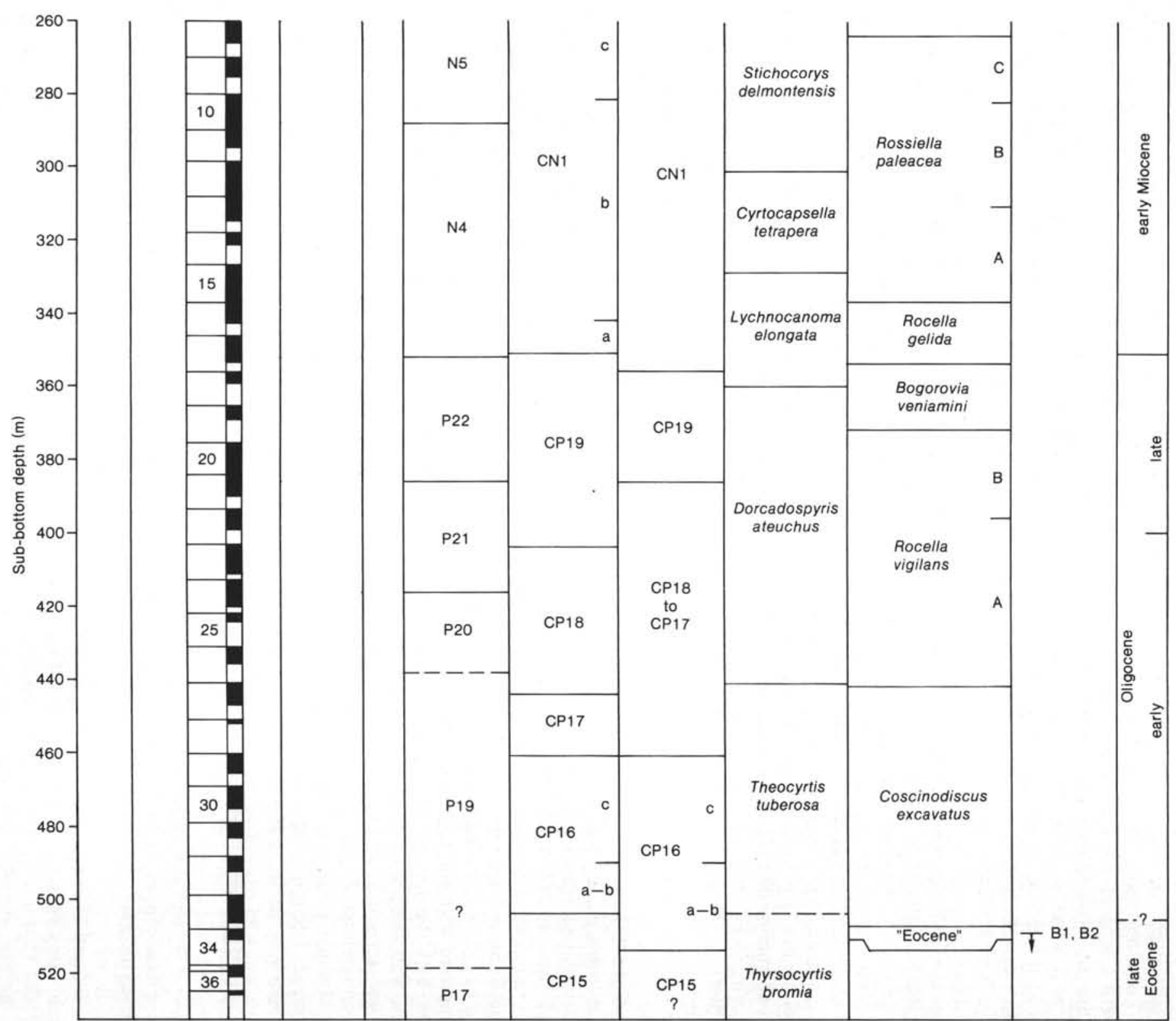

Figure 5. Coring record, biostratigraphic zonation, benthic foraminiferal events, and paleomagnetic stratigraphy at Site 574. Stratigraphy shown is for 
miniferal assemblage covered roughly the same period of time ( 18 to $13 \mathrm{Ma}$ ) at both Site 573 and Site 574 .

Weinreich and Theyer (this volume) identify paleomagnetic events between the Olduvai Event and the base of Chron 5 at Site 575 (Fig. 5). They also record the top of Chron 9 at about $79 \mathrm{~m}$ sub-bottom (lower Core 574-9); however, this interval coincides with Zone CN7, the Diartus petterssoni Zone, and the Actinocyclus moronensis Zone, and more likely represents the top of paleomagnetic Chron 11 (see Fig. 2). Barron (this volume) argues that much of paleomagnetic Chron 9 has been removed at a hiatus at about $70 \mathrm{~m}$ sub-bottom (lower Core 574-8) at Site 574, as is suggested by graphic correlation plots in a later section of this paper. Weinreich and Theyer's (this volume) extrapolations did not allow for this hiatus.

Paleomagnetic stratigraphy (Weinreich and Theyer, this volume) indicates that the Jaramillo Event of the Matuyama paleomagnetic Chron may be missing in Hole 574. Pujos ("Nannofossils from Quaternary Deposits," this volume) also reports a possible short hiatus (about 1.0 to $0.6 \mathrm{Ma}$ ) at about $5 \mathrm{~m}$ sub-bottom, in upper Core 574-2. The lithology of Core 574-2 is highly variable throughout, with alternating intervals of very pale brown, brownish gray, and dark brown siliceous and carbonate oozes (site chapter), so there is no definite lithologic evidence for a hiatus.

\section{Site 575}

Site 575, the third of the three-site south-to-north transect in the central equatorial Pacific, was occupied to extend hydraulic piston coring further back in time from the record obtained at Site 574. The second objective at Site 575-to recover a complete and undisturbed section across the Eocene/Oligocene boundary-unfortunately could not be achieved, owing to lack of time. Four holes were completed with the hydraulic piston corer (HPC) at the site, with the deepest, Hole $575 \mathrm{~A}$, extending into lowermost Miocene sediment (about $22 \mathrm{Ma}$ ) (Fig. 6).

With few exceptions, all the major microfossil groups are well represented at Site 575, and most of the early Miocene through Quaternary biozonal boundaries can be recognized. The upper $30 \mathrm{~m}$ of the section, however, accumulated very slowly, and a combination of carbonate dissolution and reworking makes zonation of this section difficult (especially for planktonic foraminifers). A 1000 -m-high seamount is located $10 \mathrm{~km}$ to the northeast of Site 575, and centimeter-thick sandy to pebbly turbidite layers, containing mostly foraminifers, basalt, and/or volcanic glass, are interbedded throughout the section.

Weinreich and Theyer's (this volume) paleomagnetic stratigraphy for Cores 575-1 through 575-4 (Fig. 7) and Cores 575A-1 through 575A-10 (Fig. 6) can be correlated with the microfossil stratigraphies for those cores, and the resultant correlations can be compared with published correlations between microfossil datum levels and paleomagnetic stratigraphy. Paleomagnetic stratigraphy was also obtained for Hole $575 \mathrm{C}$ and, in part, for Hole $575 \mathrm{~B}$, but will not be discussed here, because most microfossil studies were concentrated on material from Holes
575 and 575A. The chapters by Pujos ("Nannofossils from Quaternary Deposits," this volume, calcareous nannofossils) and Labracherie (this volume, radiolarians) discuss Quaternary correlations for Hole 575C.

Direct correlation of the $\mathrm{CN} 1 / \mathrm{CN} 2$ and Stichocorys delmontensis $/ S$. wolffii zonal boundaries with the lower normal event of Anomaly 5D (upper paleomagnetic Chron 17) (Fig. 6) implies an age of $18.2 \mathrm{Ma}$ for these boundaries, according to the paleomagnetic time scale of Berggren, Kent, and Van Couvering (in press) (Fig. 2). Gartner and Chow's placement of $\mathrm{CN} 1 / \mathrm{CN} 2$ boundary in Core 575A-10 is supported by an independent study of calcareous nannofossils by David Bukry (pers. comm., 1983), and is favored over Pujos' placement of the CN1/ CN2 boundary between Cores 575A-8 and 575A-7.

The N5/N6 boundary correlates with the normal event within Anomaly 5D, and has an estimated age of 18.1 Ma. As stated in the discussions of Sites 575 and 574, however, the N5/N6 boundary may be placed too high in Hole 575A. The Triceratium pileus/Denticulopsis nicobarica zonal boundary correlates with the middle of the upper normal event of Anomaly 5D (upper Chron $17,17.8 \mathrm{Ma}$ ), and the $\mathrm{CN} 2 / \mathrm{CN} 3$ zonal boundary is almost coincident with the top of Anomaly 5D (top of Chron 17, 17.6 Ma).

The N6/N7 and Naviculopsis ponticula/Corbisema triacantha (silicoflagellate) zonal boundaries lie immediately above the top of Anomaly 5D, in the lowermost part of paleomagnetic Chron 16 (17.5 Ma). Correlation of the N6/N7 and $\mathrm{CN} 2 / \mathrm{CN} 3$ zonal boundaries with the top of Chron 17 was suggested earlier (Ryan et al., 1974; Berggren, 1984), and is confirmed here for the first time.

The Stichocorys wolffii/Calocycletta costata zonal boundary is tied to lower Chron $16(17.3 \mathrm{Ma})$, a correlation slightly younger than the correlation with Chron 17 by Theyer et al. (1978). The Subzone A/Subzone B boundary of the Denticulopsis nicobarica Zone also falls in the lower part of Chron 16, and has an estimated age of 17.0 Ma. Finally, the Denticulopsis nicobarica/Cestodiscus peplum zonal boundary is calibrated with the upper normal event of Anomaly 5C (middle Chron 16) (16.4 Ma), a correlation younger than that with Chron 17 suggested by Burckle (1978) but consistent with the extrapolations of Barron (1983).

For the most part, correlation of planktonic microfossil datum levels and zonal boundaries with Weinreich and Theyer's paleomagnetic stratigraphy for Cores 575-1 through 575-4 (Fig. 7) agrees well with published calibrations. Events tied to paleomagnetic Chron 12, the N13/N14 boundary (Ryan et al., 1974), the CN5/CN6 boundary (Barron et al., in press), and the last occurrence of the diatom Craspedodiscus coscinodiscus (= the top of the C. coscinodiscus Zone) (Barron et al., in press) all fall within Chron 12, according to Weinreich and Theyer. Likewise, events previously calibrated with paleomagnetic Chron 10 fall within the interval Weinreich and Theyer assign to Chron 10: the CN7/CN8 boundary (Ryan et al., 1974); the transition of the radiolarian Diartus petterssoni to D. hughesi (= top of the D. petterssoni Zone) (Johnson and Wick, 1982); and the last occurrence of the diatom Actinocyclus moron- 


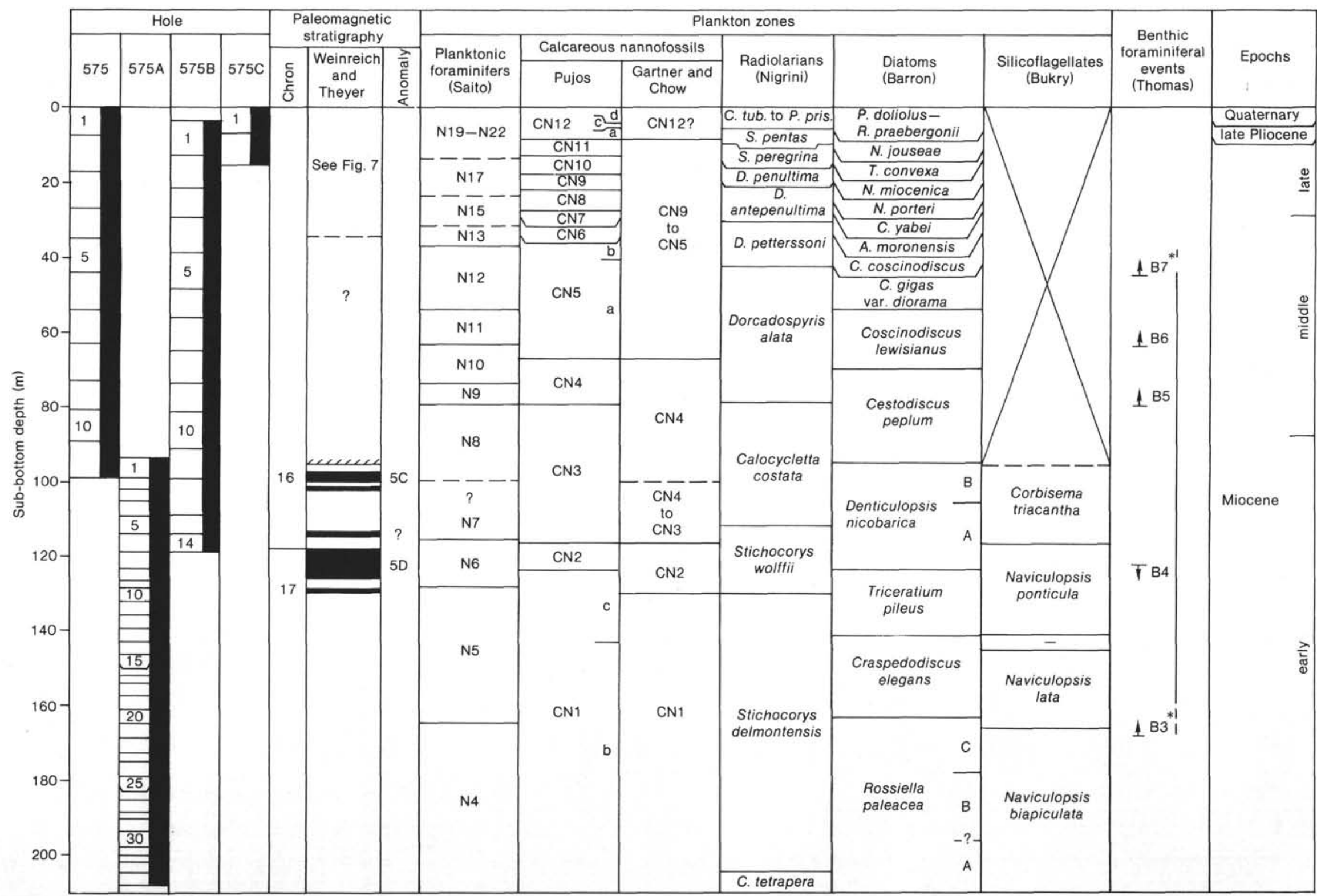

Figure 6. Coring record, biostratigraphic zonation, benthic foraminiferal events, and paleomagnetic stratigraphy for Site 575. (Detail of Cores 575-1 through 575-4 shown on Fig. 7.) Stratigraphy shown is for Holes 575 and 575A. See caption to Figure 4 for further explanation. 


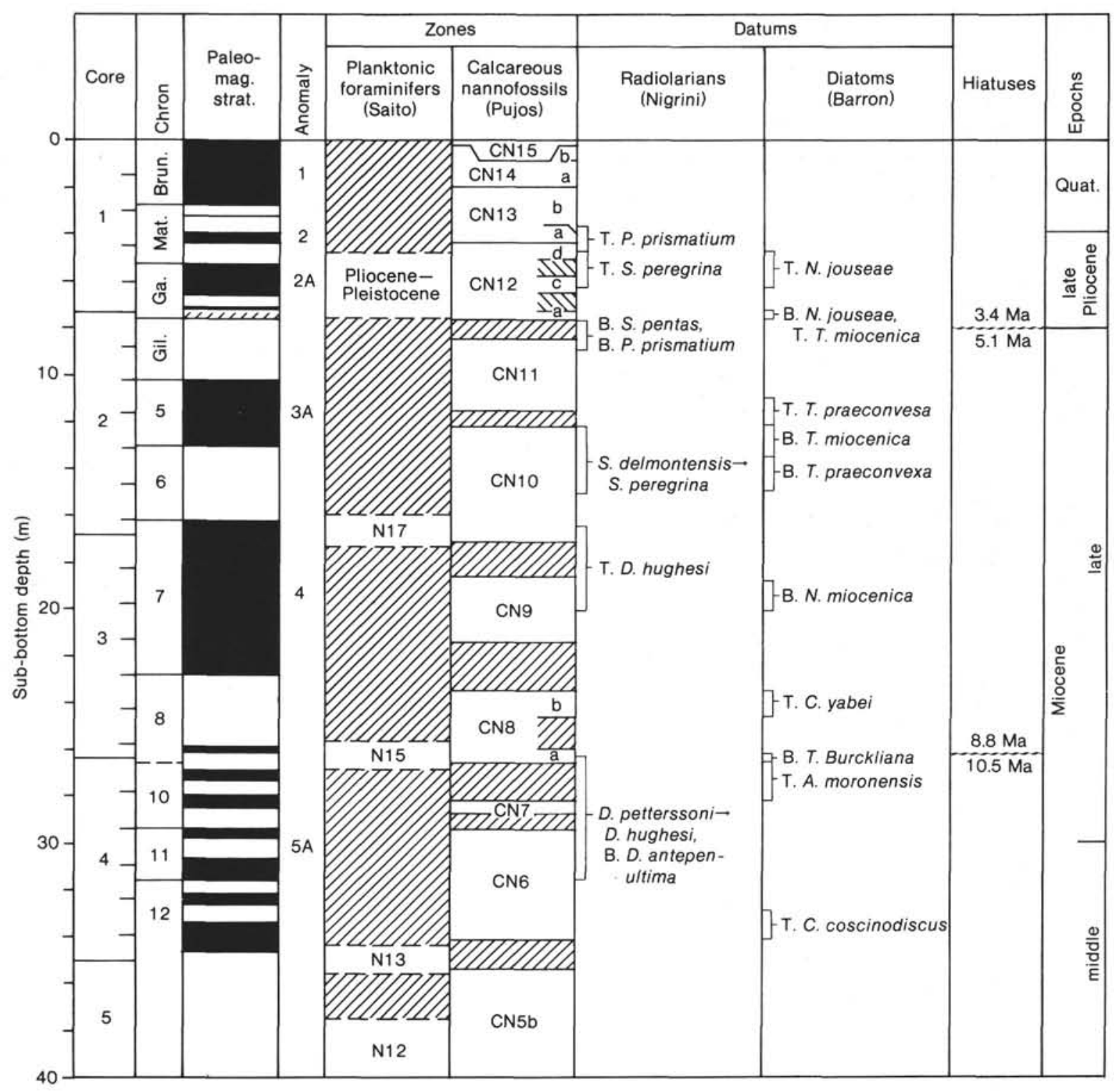

Figure 7. Paleomagnetic stratigraphy, calcareous plankton zones, and selected siliceous plankton datums for Hole 575, Cores 1 through 4. B = first occurrence (bottom); $\mathrm{T}=$ last occurrence (top). Shaded intervals have not been zoned.

ensis ( = top of the A. moronensis Zone) (Burckle, 1978). A hiatus (NH5) which removes paleomagnetic Chron 9 is shown by Weinreich and Theyer (this volume) at the base of Core 575-3, and finds supporting evidence in the diatom stratigraphy of Barron (this volume).

Interestingly, Pujos' CN8/CN9 boundary at Site 575 correlates with uppermost paleomagnetic Chron 8 near the last occurrence of the diatom Coscinodiscus yabei. This calibration agrees with the Leg 85 biostratigraphic time scale (Fig. 2), and is considerably older than Pujos' placements of the CN8/CN9 boundary at Sites 572 to 574 , in terms of both diatoms and radiolarians.

The last occurrence of Diartus hughesi ( = top of the Didymocyrtis antepenultima Zone) and first occurrence of Nitzschia miocenica ( = base of the $N$. miocenica Zone) have both been tied to paleomagnetic Chron 7 (Keller et al., 1982; Burckle, 1978), in agreement with Hole 575 paleomagnetic stratigraphy (Fig. 7), but the
CN9/CN10 boundary should correlate with the top of Chron 5 (Gartner et al., 1983). Consequently, it is assumed that Pujos' CN9/CN10 boundary in Hole 575 is placed too low; Gartner and Chow (this volume) do not recognize the CN9/CN10 boundary in Hole 575 .

Weinreich and Theyer's assignment of paleomagnetic Chron 6 is supported by the transition of the radiolarian Stichocorys delmontensis to $S$. peregrina (Theyer et al., 1978) and by the first occurrences of the diatoms Thalassiosira praeconvexa and T. miocenica (Burckle, 1978). The last occurrence of $T$. praeconvexa at about $12 \mathrm{~m}$ sub-bottom confirms paleomagnetic Chron 5 , but the CN10/CN11 boundary should lie in the upper part of the Gilbert Chron (Backman and Shackleton, 1983).

The presence of a hiatus in the uppermost part of Core 575-2, which removes almost all of the Gilbert Chron (about 5.1 to $3.4 \mathrm{Ma}$ ), is supported by the near coincidence of lowermost Gilbert events, the last occurrence 
of Thalassiosira miocenica (Burckle, 1978), and the first occurrence of Pterocanium prismatium (Theyer et al., 1978), with the base of the Gauss paleomagnetic Chron. The last occurrences of Stichocorys peregrina and Nitzschia jouseae have been tied to the upper Gauss by Theyer et al. (1978) and Burckle (1978), respectively, in agreement with the paleomagnetic stratigraphy of Weinreich and Theyer for Hole 575 (Fig. 7).

The various subzonal boundaries of calcareous nannofossil Zone CN12 recognized by Pujos at Site 575 (Fig. 7) can be compared with age estimates of Backman and Shackleton (1983) for the North Atlantic. Backman and Shackleton's (1983) ages for the CN12a/CN12b, $\mathrm{CN} 12 \mathrm{~b} / \mathrm{CN} 12 \mathrm{c}$, and $\mathrm{CN} 12 \mathrm{c} / \mathrm{CN} 12 \mathrm{~d}$ boundaries are 2.65 , 2.41 , and $2.35 \mathrm{Ma}$, respectively. Pujos does not recognize Subzone CN12b, but her CN12a/CN12c boundary is middle Gauss, or approximately 3.1 to $2.8 \mathrm{Ma}$. Pujos' $\mathrm{CN} 12 \mathrm{c} / \mathrm{CN} 12 \mathrm{~d}$ boundary is near the top of the Gauss, and could be as young as Backman and Shackleton's (1983) $2.35 \mathrm{Ma}$.

Backman and Shackleton (1983) estimate the age of the $\mathrm{CN} 12 / \mathrm{CN} 13$ boundary, the last occurrence of Discoaster brouweri, at $1.88 \mathrm{Ma}$, near the base of the Olduvai Event. Pujos's assignment of the CN12/CN13 boundary in Hole 575 lies very close to the base of Weinreich and Theyer's Olduvai Event (Fig. 7).

\section{GRAPHIC CORRELATION PLOTS}

To refine correlations between the individual sites and to evaluate the completeness of the stratigraphic sections, graphic correlation plots have been constructed for four stratigraphic intervals: the uppermost Eocene to lowermost Miocene of Sites 573 and 574 (Fig. 8); the lower Miocene of Sites 573, 574, and 575 (Fig. 9); the middle Miocene and most of the upper Miocene (to 6.2 Ma) of Sites 572, 573, and 574 (Fig. 10); and the uppermost Miocene through Quaternary of Sites 572 and 573 (Fig. 11). Graphic correlation plots allow comparison of the stratigraphic sequencing of the numerous datum levels identified for planktonic foraminifers (Saito, this volume), calcareous nannofossils (Pujos, both chapters, this volume; Gartner and Chow, this volume), radiolarians (Nigrini, this volume; Labracherie, this volume), diatoms (Barron, this volume; Baldauf, this volume), and benthic foraminifers (Thomas, this volume). Diachronous datum levels can be identified, and a best-fit correlation plot between sections can be produced (Shaw, 1964). In addition, other stratigraphic events-paleomagnetic, carbonate, isotopic, and lithologic-can be used on such plots to greatly refine correlations. Correlation of carbonate, isotope, and lithologic events is not attempted here, but carbonate and isotopic tuning of the record is addressed in the chapter by Pisias and Prell (this volume). Construction of graphic correlation plots is also a convenient way of relating the datum levels of different microfossil groups. Where individual datum levels of one microfossil group have been directly calibrated to paleomagnetic stratigraphy, indirect correlation of other datum levels with paleomagnetic stratigraphy is often possible.

Tables 2 to 6 list the radiolarian, diatom, calcareous nannofossil, planktonic foraminiferal, and benthic fora-
Table 2. Radiolarian datum levels used for correlations on Figures 3 to 13 .

\begin{tabular}{|c|c|c|c|}
\hline \multirow[b]{2}{*}{ Event } & \multirow[b]{2}{*}{ Datum $^{a}$} & \multicolumn{2}{|c|}{ Age (Ma) } \\
\hline & & $\begin{array}{l}\text { Paleomagnetic } \\
\text { correlation }^{b}\end{array}$ & $\begin{array}{l}\text { Extrapolated } \\
\text { (this chapter) }^{\mathrm{C}}\end{array}$ \\
\hline $\mathrm{R} 60$ & Buccinosphaera invaginata & $0.65-0.72^{\mathrm{d}}$ & \\
\hline R59 & Collosphaera tuberosa & $0.28^{\mathrm{e}}$ & \\
\hline R58 & Axoprunum angelinum & $0.42^{\mathrm{e}}$ & \\
\hline R57 & Amphispyris roggentheni & $0.78^{\mathrm{e}}$ ? & \\
\hline R56 & Anthocyrtidium angulare & $1.05^{\mathrm{e}}$ & \\
\hline R55 & Theocorythium vetulum & $1.20^{\mathrm{e}}$ & \\
\hline R54 & Pterocanium prismatium & $1.6^{\mathrm{e}}$ & \\
\hline R53 & Stichocorys peregrina & $2.4^{f}$ & \\
\hline R52 & Spongaster pentas & $3.4^{\mathrm{f}}$ & \\
\hline R51 & $\begin{array}{l}\text { T. Didymocyrtis penultima } \\
\text { B. Spongaster tetras }\end{array}$ & $\begin{array}{l}3.7^{f} \\
3.6^{f}\end{array}$ & \\
\hline R50 & Spongaster berminghami & & $4.2-4.3$ \\
\hline R49 & Botryostrobus bramlettei & & 4.6 \\
\hline R48 & Pterocanium prismatium & $4.8^{f}$ & \\
\hline \multirow[t]{2}{*}{ R47 } & Botryostrobus aquilonaris & & 5.1 \\
\hline & Siphostichartus corona & & 5.1 \\
\hline R46 & Acrobotrys tritubus & $5.5^{\mathrm{g}}, 5.0^{\mathrm{f}}$ & 5.5 \\
\hline R45 & Calocycletta caepa & & 5.6 \\
\hline $\mathrm{R} 44$ & $\begin{array}{l}\text { Stichocorys delmontensis } \rightarrow \\
\text { S. peregrina }\end{array}$ & $6.2^{f}$ & \\
\hline R43 & B. Solenosphaera omnitubus & $7.3^{8}$ & \\
\hline R42 & Diartus hughesi & 7.98 & \\
\hline \multirow[t]{2}{*}{ R41 } & Botryostrobus miralestensis & & $8.8-8.9$ \\
\hline & Dictyocorne ontongensis & & $8.8-8.9$ \\
\hline \multirow[t]{2}{*}{ R40 } & Didymocyrtis penultima & $9.8^{8}$ & \\
\hline & Diartus petterssoni & $10.4^{\mathrm{g}}$ & $9.8-10.0$ \\
\hline R39 & Diartus hughesi & $11.5^{f}$ & $10.4-11.2$ \\
\hline R38 & Stichocorys wolffii & $10.4^{8}$ & 10.8 \\
\hline R37 & Cyrtocapsella japonica & $11.5^{\mathrm{d}}$ & 11.4 \\
\hline R36 & Spirocyrtis subtilis & & 11.5 \\
\hline R35 & Didymocyrtis antepenultima & $11.5^{\mathrm{f}}$ & \\
\hline R34 & Cyrtocapsella cornuta & $12.5^{\mathrm{g}}$ & $12.6-12.7$ \\
\hline R33 & Lithopera renzae & & $12.6-12.8$ \\
\hline R32 & Dorcadospyris alata & $11.3^{f}, 12.8^{d}$ & $12.8-14.5$ \\
\hline R31 & Giraffospyris toxaria & & $12.9-13.0$ \\
\hline R30 & Diartus petterssoni & $12.6^{\mathrm{d}}$ & $12.8-13.3$ \\
\hline R29 & Lithopera thornburgi & $>13.5^{\mathrm{d}}$ & 13.6 \\
\hline R28 & Didymocyrtis laticonus & $13.8^{\mathrm{f}}$ & \\
\hline \multirow[t]{2}{*}{ R27 } & Calocycletta costata & $14.8^{8}$ & \\
\hline & Didymocyrtis tubaria & & $14.7-14.8$ \\
\hline \multirow[t]{2}{*}{ R26 } & Dorcadospyris dentata & $15.3^{\mathrm{f}}$ & \\
\hline & Didymocyrtis violina & & $15.0-15.3$ \\
\hline R25 & Dorcadospyris forcipatata & & $15.2-15.3$ \\
\hline & Liriospyris stauropora & & $15.2-15.3$ \\
\hline R24 & Dorcadospyris alata & $15.5^{f}$ & \\
\hline R23 & Liriospyris parkerae & & $16.1-16.4$ \\
\hline R22 & Giraffospyris toxaria & $16.5^{\mathrm{h}}$ & \\
\hline R21 & Calocycletta costata & $17.3^{\mathrm{h}}$ & \\
\hline R20 & Stichocorys wolfffii & $18.2^{\mathrm{h}}$ & \\
\hline & Dorcadospyris ateuchus & $18.2^{\mathrm{h}}$ & \\
\hline R19 & Siphostichartus corona & $18.2^{\mathrm{h}}$ & $18.2-19.8$ \\
\hline R18 & B. Didymocyrtis tubaria & $20.3^{\mathrm{g}}$ & \\
\hline & B. Didymocyrtis violina & $20.2^{f}$ & \\
\hline R17 & B. Stichocorys deimontensis & $21.1^{\mathrm{f}}$ & $20.3-20.5$ \\
\hline R16 & Theocyrtis annosa & $21.3 \mathrm{f}$ & 20.9 \\
\hline R15 & Calocycletta virginis & $21.5^{\mathrm{f}}$ & \\
\hline R14 & Cyclampterium pegetrum & & $21.9-22.1$ \\
\hline R13 & Cyrtocapsella cornuta & $22.1^{\mathrm{g}}$ & \\
\hline & Cyrtocapsella tetrapera & $22.1^{8}$ & \\
\hline $\mathrm{R} 12$ & Carpocanopsis favosa & & $22.4-22.6$ \\
\hline RII & Artophormis gracilis & $22.6^{\mathrm{g}}$ & \\
\hline R10 & B. Lychnocanoma elongata & $24.1^{\mathrm{f}} \mathrm{e}$ & \\
\hline R9 & B. Calocycletta robusta & $25.5^{\mathrm{f}}$ & \\
\hline R8 & B. Dorcadospyris forcipata & & $28.0-28.5$ \\
\hline R7 & Lithocyclia angustata & & $31.8-32.0$ \\
\hline R6 & Theocyrtis anna & & $32.2-32.8$ \\
\hline R5 & T. Lithocyclia crux & & $32.1-33.6 ?$ \\
\hline R4 & B. Dorcadospyris ateuchus & $33.0^{\mathrm{i}}$ & \\
\hline & Tristylospyris triceros & & $32.8-33.5$ \\
\hline & Cyclampterium milowi & & $32.8-33.5$ \\
\hline R3 & B. Eucyrtidium diaphanes & & $33.6-33.8$ \\
\hline & T. Theocyrtis tuberosa & & $33.6-33.8$ \\
\hline R2 & B. Lithocyclia angustata & & 34.6 \\
\hline RI & $\begin{array}{l}\text { lowermost Theocyrtis tuberosa } \\
\text { Zone }\end{array}$ & & $36.4-36.6$ \\
\hline
\end{tabular}

Note: Asterisks identify reinterpreted paleomagnetic chron assignments.

$\mathrm{T}$. $=$ top; $\mathrm{B}$. = bottom.

Absolute age estimates are from direct and indirect correlations with paleomagnetic stratigraphy. The paleomagnetic time scale of Berggren et al. (in press) is used; see Addendum and Table 8.

- Extrapolated age estimates are from Figures 12 and 13.

d Johnson and Wick (1982)

e Labracherie (this volume).

f Theyer et al. (1978).

8 Barron et al. (in press)

h Leg 85 paleomagnetic calibration in Hole $575 \mathrm{~A}$.

i F. Theyer (unpubl. data). 
Table 3. Diatom datum levels used for correlations on Figures 3 to 13.

\begin{tabular}{|c|c|c|c|c|}
\hline \multirow[b]{2}{*}{ Event } & \multirow{2}{*}{\multicolumn{2}{|c|}{ Datum $^{\mathrm{a}}$}} & \multicolumn{2}{|c|}{ Age (Ma) } \\
\hline & & & $\begin{array}{l}\text { Paleomagnetic } \\
\text { correlation }^{b}\end{array}$ & $\begin{array}{l}\text { Extrapolated } \\
\text { (this chapter })^{\mathrm{C}}\end{array}$ \\
\hline D43 & $\mathbf{T}$. & Nitzschia reinholdii & $0.65^{\mathrm{d}}$ & $0.65-0.70$ \\
\hline D42 & T. & Rhizosolenia praebergonii var. robusta & $1.6^{\mathrm{e}}$ & \\
\hline D41 & B. & Pseudoeunotia doliolus & $1.8^{\mathrm{e}}$ & $1.8-2.0 ?$ \\
\hline D40 & T. & Thalassiosira convexa & $2.2^{e}$ & \\
\hline D39 & T. & Nitzschia jouseae & $2.6^{\mathrm{e}}$ & \\
\hline D38 & B. & Rhizosolenia praebergonii & $3.0^{e}$ & \\
\hline D37 & B. & Asterolampra elegans & $3.9^{\mathrm{e}}$ & \\
\hline D36 & T. & Nitzschia cylindrica & $4.4^{\mathrm{e}}$ & \\
\hline D35 & B. & Nitzschia jouseae & $4.6^{\mathrm{e}}$ & \\
\hline D34 & T. & Thalassiosira miocenica & $5.1^{\mathrm{e}}$ & \\
\hline D33 & T. & Asterolampra acutiloba & $5.35^{\mathrm{e}}$ & \\
\hline D32 & T. & Nitzschia miocenica & $5.6^{\mathrm{e}}$ & \\
\hline D31 & $\mathrm{T}$. & Nitzschia miocenica var. elongata & $5.65^{\mathrm{f}}$ & \\
\hline D30 & $\mathrm{T}$. & Thalassiosira praeconvexa & $5.8^{\mathrm{e}}$ & \\
\hline D29 & B. & Thalassiosira convexa & $6.2^{\mathrm{e}}$ & \\
\hline D28 & B. & Thalassiosira praeconvexa & $6.3^{\mathrm{e}}$ & \\
\hline D27 & B. & Nitzschia miocenica & $7.3^{\mathrm{e}}$ & \\
\hline D26 & $\mathrm{T}$. & Thalassiosira burckliana & $8.0^{\mathrm{e}}$ & \\
\hline D25 & T. & Coscinodiscus yabei & $8.6^{\mathrm{e}}$ & \\
\hline D24 & B. & Nitzschia fossilis & & 9.8 \\
\hline D23 & B. & Thalassiosira burckliana & $9.0^{\mathrm{e}}$ & $10.5-10.6$ \\
\hline D22 & $\tau$ & Coscinodiscus vetustissimus var. javanica & $10.7^{\mathrm{e}}$ & \\
\hline D21 & B. & Coscinodiscus vetustissimus var. javanica & $11.2^{\mathrm{e}}$ & \\
\hline D20 & $\mathrm{T}$. & Actinocyclus moronensis & $11.3^{\mathrm{e}}$ & \\
\hline D19 & I. & Coscinodiscus tuberculatus & $12.0^{g}$ & \\
\hline D18 & T. & Craspedodiscus coscinodiscus & $12.2^{\mathrm{h}}$ & \\
\hline D17 & B. & Hemidiscus cuneiformis & $12.6^{\mathrm{e}}$ & \\
\hline D16 & B. & Coscinodiscus temperei var. delicata & $12.8^{\mathrm{g}}$ & \\
\hline D15 & T. & Coscinodiscus lewisianus & $13.5^{i}$ & \\
\hline D14 & $\mathrm{T}$. & Cestodiscus peplum & $14.2^{\mathrm{e}}$ & \\
\hline D13 & $\mathrm{T}$. & Annelius californicus & $15.0^{\mathrm{e}}$ & \\
\hline D12 & B. & Cestodiscus peplum & $16.4^{\mathrm{h}}$ & \\
\hline D11 & T. & Thalassiosira bukryi & $17.0^{\mathrm{h}}$ & \\
\hline D10 & B. & Denticulopsis nicobarica & $17.8^{\mathrm{h}}$ & \\
\hline D9 & $\mathrm{T}$. & Craspedodiscus elegans & $18.7^{\mathrm{i}}$ & 18.4-18.5 \\
\hline D8 & T. & Bogorovia veniamini & $19.9^{f}$ & $19.5-19.7$ \\
\hline D7 & T. & Coscinodiscus oligocenicus & $20.6^{i}$ & 20.2 \\
\hline D6 & T. & Thalassiosira primalabiata & $21.7^{i}$ & $20.7-21.7$ \\
\hline DS & B. & Actinocyclus hajosiae & & 21.0 \\
\hline D4 & B. & Rocella gelida & & $23.8-24.0$ \\
\hline D3 & B. & Bogorovia veniamini & & $26.4-27.3$ \\
\hline D2 & T. & Cestodiscus mukhinae & & $28.5-28.7$ \\
\hline DI & T. & Coscinodiscus excavatus & & $33.0 \pm$ \\
\hline
\end{tabular}

a $\mathrm{T}$. = top; B. = bottom.

Absolute age estimates are from direct and indirect correlations with paleomagnetic stratig.

raphy. The paleomagnetic time scale of Berggren et al. (in press) is used.

c Extrapolated age estimates are from Figures 12 and 13.

d Burckle (1972).

E Burckle (1978).

L. H. Burckle (pers. comm., 1980).

g Burckle et al. (1982).

$\mathrm{h}$ Leg 85 paleomagnetic calibration in Hole 575A.

miniferal datum levels (or zonal boundaries) used in the graphic correlation plots. Published age estimates of these datum levels from direct and indirect calibrations with paleomagnetic stratigraphy are also included. The majority of datums used here are those of radiolarians and diatoms, because Nigrini, Labracherie, and Barron (all this volume) have provided tables giving the stratigraphic positions of numerous datums in the sections at Sites 572 to 575 . Calcareous microfossil datums used for correlations are mostly zonal and subzonal boundaries, although Pujos ("Nannofossils from Quaternary Deposits," this volume) provides correlation of numerous Quaternary calcareous nannofossil datums at Sites 571 to 575.

\section{Uppermost Eocene to Lowermost Miocene}

Graphic correlation of the uppermost Eocene to lowermost Miocene sections at Sites 573 and 574 is shown on Figure 8. The correlation between the two sections is well constrained by 12 radiolarian, 4 diatom, 7 calcareous nannofossil, 5 planktonic foraminiferal, and 2 ben-

Table 4. Planktonic foraminiferal datum levels (and zonal boundaries) used for correlations on Figures 3 to 13.

\begin{tabular}{|c|c|c|c|c|}
\hline \multirow[b]{2}{*}{ Event } & & \multirow{2}{*}{ Datum ${ }^{\mathrm{a}}$} & \multicolumn{2}{|c|}{ Age (Ma) } \\
\hline & & & $\begin{array}{l}\text { Paleomagnetic } \\
\text { correlation }^{b}\end{array}$ & $\begin{array}{c}\text { Extrapolated } \\
\text { (this chapter) }^{\mathrm{c}}\end{array}$ \\
\hline P14 & & $\mathrm{N} 21 / \mathrm{N} 22$ & $1.9^{\mathrm{d}}$ & \\
\hline P13 & $\mathrm{T}$. & Sphaeroidinella seminulina & $3.05^{\mathrm{d}}$ & \\
\hline P12 & & N18/N19 & $4.9^{\mathrm{a}}$ & $4.6-4.8$ \\
\hline P11 & & $\mathrm{N} 16 / \mathrm{N} 17$ & $9.0^{\mathrm{e}}$ & $9.8-10.7$ \\
\hline P10 & & $\mathrm{N} 11 / \mathrm{N} 12$ & $13.7^{\mathrm{e}}$ & 13.6 \\
\hline P9 & & N10/N11 & $14.2^{\mathrm{e}}$ & 14.0 \\
\hline P8 & & N8/N9 & $15.2^{\mathrm{f}}$ & \\
\hline P7 & & N5/N6 & $18.1^{\mathrm{g}}$ & $18.1-19.0$ \\
\hline P6 & & N4/N5 & $20.1^{\mathrm{e}}$ & $20.1-20.6$ \\
\hline P5 & & $\mathrm{P} 22 / \mathrm{N} 4$ & $23.7^{\mathrm{f}}$ & \\
\hline P4 & & $\mathrm{P} 21 / \mathrm{P} 22$ & $28.2^{\mathrm{f}}$ & \\
\hline P3 & & $\mathrm{P} 20 / \mathrm{P} 21$ & $31.6 \mathrm{f}$ & \\
\hline P2 & & P19/P20 & $32.7_{\mathrm{f}}^{\mathrm{f}}-\mathrm{r}-\mathrm{s}$ & \\
\hline P1 & & P16/P17 & $36.3^{\mathrm{f}}$ & \\
\hline
\end{tabular}

${ }^{\mathrm{a}} \mathrm{T} .=$ top.

b Absolute age estimates are from direct and indirect correlations with paleomagnetic stratigraphy. The paleomagnetic time scale of Berggren et al. (in press) is used.

c Extrapolated age estimates are from Figures 12 and 13.

d Saito et al. (1975).

e Barron et al. (in press).

f Poore et al. (1983).

$\mathrm{g}^{\mathrm{g}}$ Leg 85 paleomagnetic calibration in Hole 575A.

Table 5. Calcareous nannofossil datum levels (and zonal and subzonal boundaries) used for correlations on Figures 3 to 13 .

\begin{tabular}{|c|c|c|c|c|}
\hline \multirow[b]{2}{*}{ Event } & \multirow{2}{*}{\multicolumn{2}{|c|}{ Datum $^{a}$}} & \multicolumn{2}{|c|}{ Age (Ma) } \\
\hline & & & $\begin{array}{l}\text { Paleomagnetic } \\
\text { correlation } \mathrm{b}\end{array}$ & $\begin{array}{c}\text { Extrapolated } \\
\text { (this chapter) }^{\mathrm{c}}\end{array}$ \\
\hline $\mathrm{N} 20$ & T. & Pseudoemiliana lacunosa & $0.47^{\mathrm{d}}$ & \\
\hline N19 & & $\mathrm{CN} 12 / \mathrm{CN} 13$ & $1.88^{\mathrm{e}}$ & \\
\hline N18 & & $\mathrm{CN} 11 / \mathrm{CN} 12$ & $3.56^{\mathrm{e}}$ & 3.5 \\
\hline N17 & & $\mathrm{CN} 9 / \mathrm{CN} 10$ & $5.5^{\mathrm{f}}$ & $5.1-5.2$ \\
\hline N16 & & $\mathrm{CN} 8 / \mathrm{CN} 9$ & $8.3^{\mathrm{g}}$ & 6.0 (Pujos) \\
\hline N15 & & $\mathrm{CN} 7 / \mathrm{CN} 8$ & $11.1^{\mathrm{h}}$ & \\
\hline $\mathrm{N} 14$ & & $\mathrm{CN} 6 / \mathrm{CN} 7$ & $12.0_{i}^{i}$ & $11.7-11.8$ \\
\hline $\mathrm{N} 13$ & & $\mathrm{CN} 5 / \mathrm{CN} 6$ & $12.3^{i}$ & \\
\hline N12 & & $\mathrm{CN} 5 \mathrm{a} / \mathrm{CN} 5 \mathrm{~b}$ & $12.8_{i}^{\mathrm{i}}$ & \\
\hline N11 & & $\mathrm{CN} 4 / \mathrm{CN} 5$ & $14.1^{\mathrm{i}}$ & $13.7-14.0$ \\
\hline N10 & & $\mathrm{CN} 3 / \mathrm{CN} 4$ & $15.7^{\mathrm{i}}$ & \\
\hline N9 & & $\mathrm{CN} 2 / \mathrm{CN}_{3}$ & $17.5_{\mathrm{i}}^{\mathrm{j}}$ & \\
\hline N8 & & $\mathrm{CN} 1 / \mathrm{CN} 2$ & $18.2^{\mathrm{j}}$ & \\
\hline N7 & & $\mathrm{CN} 1 \mathrm{a} / \mathrm{CN} 1 \mathrm{~b}$ & $22.7^{i}$ & \\
\hline N6 & & CP19/CN1 & $23.7^{\mathrm{k}}$ & \\
\hline N5 & & CP18/CP19 & $30.7^{k}$ & \\
\hline $\mathrm{N} 4$ & & CP17/CP18 & $33.3 \mathrm{l}$ & \\
\hline N3 & & CP16/CP17 & $34.6^{k}$ & \\
\hline $\mathrm{N} 2$ & & CP16b/CP16c & $35.0^{\mathrm{k}}$ & \\
\hline N1 & & CP15/CP16 & $36.8^{k}$ & \\
\hline
\end{tabular}

a $\mathrm{T}$. $=$ top.

b Absolute age estimates are from direct and indirect correlations with paleomagnetic stratigraphy. The paleomagnetic time scale of Berggren et al. (in press) is used.

c Extrapolated age estimates are from Figures 12 and 13.

d Berggren et al. (1980).

e Backman and Shackleton (1983).

f Gartner (1973).

g Haq et al. (1980).

h Leg 85 paleomagnetic calibration in Hole 575A.

i Barron et al. (in press).

j Ryan et al. (1974).

$\mathrm{k}$ Poore et al. (1983)

1 Lowrie et al. (1982). 
Table 6. Benthic foraminiferal datum levels used for Leg 85 correlations.

\begin{tabular}{lllll}
\hline & & & \multicolumn{2}{c}{ Age (Ma) } \\
\cline { 4 - 5 } Event & & \multicolumn{1}{c}{ Datum $^{\text {a }}$} & $\begin{array}{c}\text { Paleomagnetic } \\
\text { correlation }^{b}\end{array}$ & $\begin{array}{c}\text { Extrapolated } \\
\text { (this chapter) }\end{array}$ \\
\hline B7 & B. & Melonis pompilioides & & $13.0-13.1$ \\
B6 & B. & Francesita advena & & $13.4-14.6$ \\
B5 & B. & Cibicidoides wuellerstorfi & & $14.7-15.4$ \\
B4 & T. & Cibicidoides laurisae & & $17.2-17.7$ \\
B3 & B. & Melonis barleeanus & About $36.5^{\mathrm{C}}$ & $18.8-19.8$ \\
B2 & T. & Nuttallides truempyi & About 36.5 \\
B1 & T. & Alabamina dissonata & &
\end{tabular}

a B. = bottom; T. = top.

${ }^{b}$ Extrapolated age estimates are from Figures 12 and 13.

c Tjalsma and Lohmann (1983). thic foraminiferal datum levels. Only the R5 datum level, the last occurrence of the radiolarian Lithocyclia crux, lies off the correlation line, although Pujos' N5 datum (the CP18/CP19 boundary) also appears off the line. The general relationship suggests that the Site $573 \mathrm{sec}$ tion accumulated at a rate typically about twice that of the Site 574 section throughout most of the Oligocene, except during two hiatuses and one compressed interval (possibly a hiatus) (Fig. 8). During the early Oligocene interval of calcareous nannofossil Zone CP16 (datums $\mathrm{N} 1$ to $\mathrm{N} 3$, or 36.8 to $34.6 \mathrm{Ma}$ ), accumulation rates at Sites 573 and 574 are approximately equal (Fig. 8).

The Eocene/Oligocene hiatus mentioned in the discussion of Site 573 is apparent at about $525 \mathrm{~m}$ sub-bottom at Site 573. This hiatus appears to cover at least the interval from the base of Zone P17 (37.3 Ma) to the top of Zone CP15 (36.8 Ma) (Table 7). An Oligocene/Miocene hiatus (hiatus $\mathrm{PH}$ ) at nearby Site 77 , mentioned by

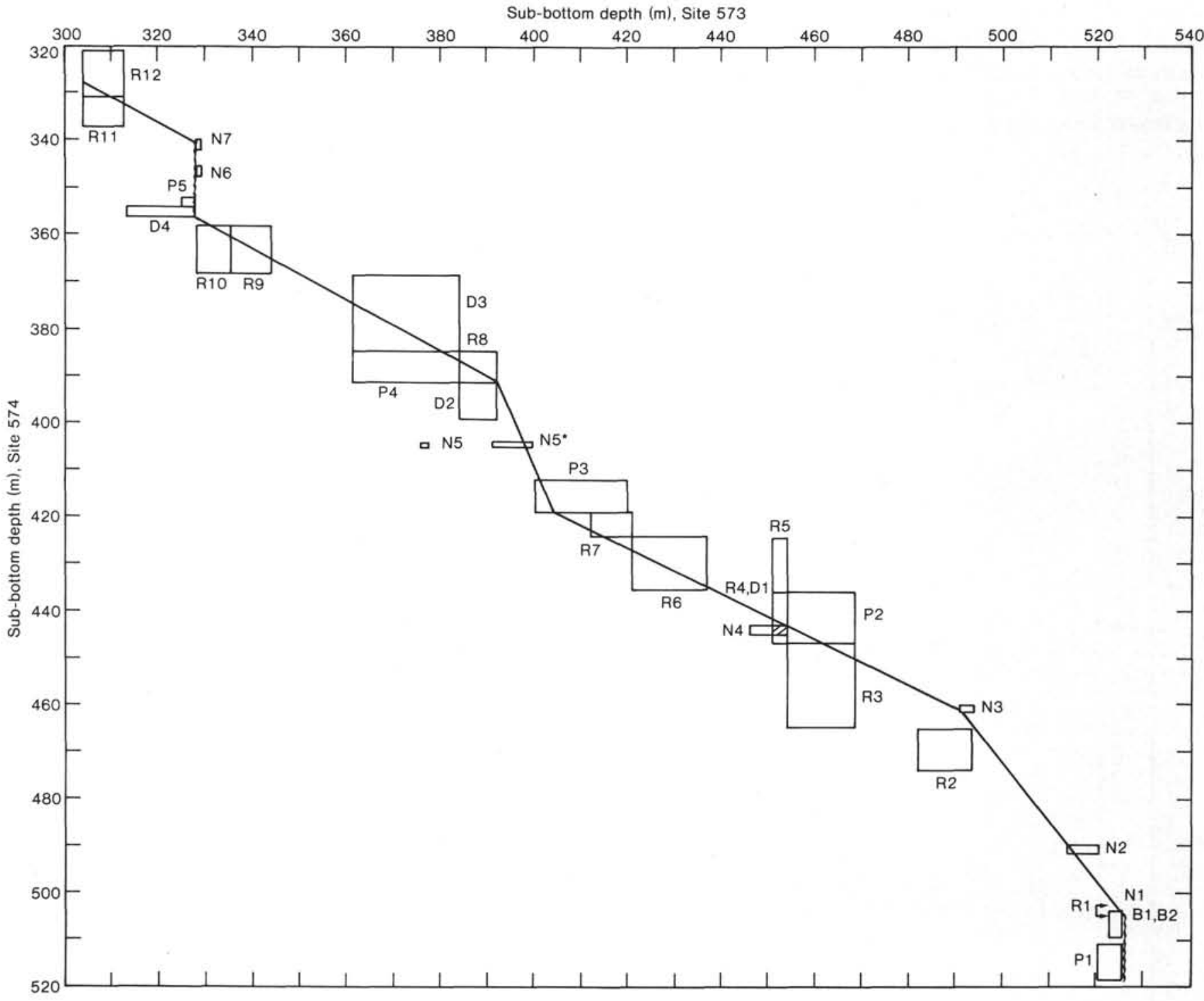

Figure 8. Graphic correlation of the uppermost Eocene to lowermost Miocene sections at Sites 573 and 574. Boxes constrain the stratigraphic positions of the microfossil datums used for the correlation-refer to Tables 2 to 6 . Overlaps of boxes are shaded. Calcareous nannofossil datum levels used are those of Pujos (this volume), except for those marked with an asterisk, which are from Gartner and Chow (this volume). 


\section{J. A. BARRON ET AL.}

Table 7. Summary of hiatuses and compressed intervals in Leg 85 sediment.

\begin{tabular}{|c|c|c|c|c|c|}
\hline Site & $\begin{array}{l}\text { Sub-bottom } \\
\text { depth (m) }\end{array}$ & Age (Ma) & $\begin{array}{l}\text { Hiatus }(\mathrm{H}) \text { or } \\
\text { compressed }(\mathrm{C})\end{array}$ & $\begin{array}{l}\text { Lithologic } \\
\text { change }\end{array}$ & $\begin{array}{l}\text { Recorded } \\
\text { elsewhere }\end{array}$ \\
\hline 573 & 76 & $4.6-5.1$ & $\mathrm{H}$ ? & Yes & $\mathrm{NH}^{\mathrm{a}}$ \\
\hline 573 & 158 & $9.8-10.5$ & $\mathrm{H}$ & Yes & $\mathrm{NH}^{\mathrm{a}}$ \\
\hline 573 & 177 & $11.5-12.0$ & $\mathrm{H}$ & No & $\mathrm{NH}_{4}{ }^{\mathrm{a}}$ \\
\hline 573 & 187 & $12.3-12.7$ & $\mathrm{H}$ ? or $\mathrm{C}$ & No & $\mathrm{NH} 3 ?^{\mathrm{a}}$ \\
\hline 573 & 272 & $18.2-19.7$ & $\mathrm{H}$ & Yes $^{b}$ & $\mathrm{NH} \mathrm{b}^{\mathrm{a}}$ \\
\hline 573 & 290 & $20.5-21.5$ & $\mathrm{H}$ & Yes & $\mathrm{NH} \mathrm{a}^{\mathrm{a}}$ \\
\hline 573 & 328 & $22.7-24.0$ & $\mathrm{H}$ & No & $\mathrm{PH}^{\mathrm{a}}$ \\
\hline 573 & $392-404$ & $28.7-32.0$ & $\mathrm{C}$ & No & c \\
\hline 573 & 525 & $36.8-37.3$ & $\mathrm{H}$ & Yes & $\mathrm{d}$ \\
\hline 574 & 5 & $0.6-1.0$ & $\mathrm{H}$ & Yes? & \\
\hline 574 & 70 & $9.8-11.1$ & $\mathrm{H}$ & Yes & $\mathrm{NH}^{\mathrm{a}}$ \\
\hline 575 & 8 & $3.4-5.1$ & $\mathrm{H}$ & No & $\mathrm{NH}^{\mathrm{a}, \mathrm{e}}$ \\
\hline 575 & 26 & $8.8-10.5$ & $\mathrm{H}$ & No & $\mathrm{NH} 5^{\mathrm{a}}$ \\
\hline
\end{tabular}

${ }^{\mathrm{a}}$ Keller and Barron (1983).

$\mathrm{b}$ Downhole change in diatom preservation.

c Keller (1983a).

d Kennett et al. (1975).

e Osborn et al. (1983).

Hays et al. (1972) and Keller and Barron (1983), is present at about $328 \mathrm{~m}$ sub-bottom at Site 573 . As noted by Pujos ("Cenozoic Nannofossils," this volume), this hiatus removes calcareous nannofossil Subzone CN1a. An estimated duration of 24.0 to $22.7 \mathrm{~m}$.y. for this Oligocene/Miocene hiatus is suggested by the Leg 85 biostratigraphic time scale (Fig. 2, Table 7).

A compressed interval is present at Site 573 within planktonic foraminiferal Zone P21 (datums P3 to P4, 404 to $392 \mathrm{~m}$ sub-bottom). This compressed interval in Zone P21 (31.6 to $28.2 \mathrm{Ma}$ ) coincides with a widespread deep-sea hiatus (Keller, 1983a), major lowering of sea level (Vail and Hardenbol, 1979), and oxygen-isotope enrichment in benthic foraminiferal tests both at Site 77 (Keigwin and Keller, 1984) and at Site 574 (Miller and Thomas, this volume).

\section{Lower Miocene}

Graphic correlation plots for the lower Miocene sections at Sites 573, 574, and 575 are shown on Figure 9. The records at Sites 574 and 575 are quite similar, without any apparent hiatuses, whereas one major or two lesser hiatuses are predicted within the Site 573 section.

Most of the 23 datum levels correlated between Sites 574 and 575 lie on or very close to the plotted line of correlation. The exceptions are events D6 (the last occurrence of Thalassiosira primalabiata), P6 (the N4/N5 boundary), P7 (the N5/N6 boundary), and B3 (the first occurrence of Melonis barleeanus). Barron (this volume)

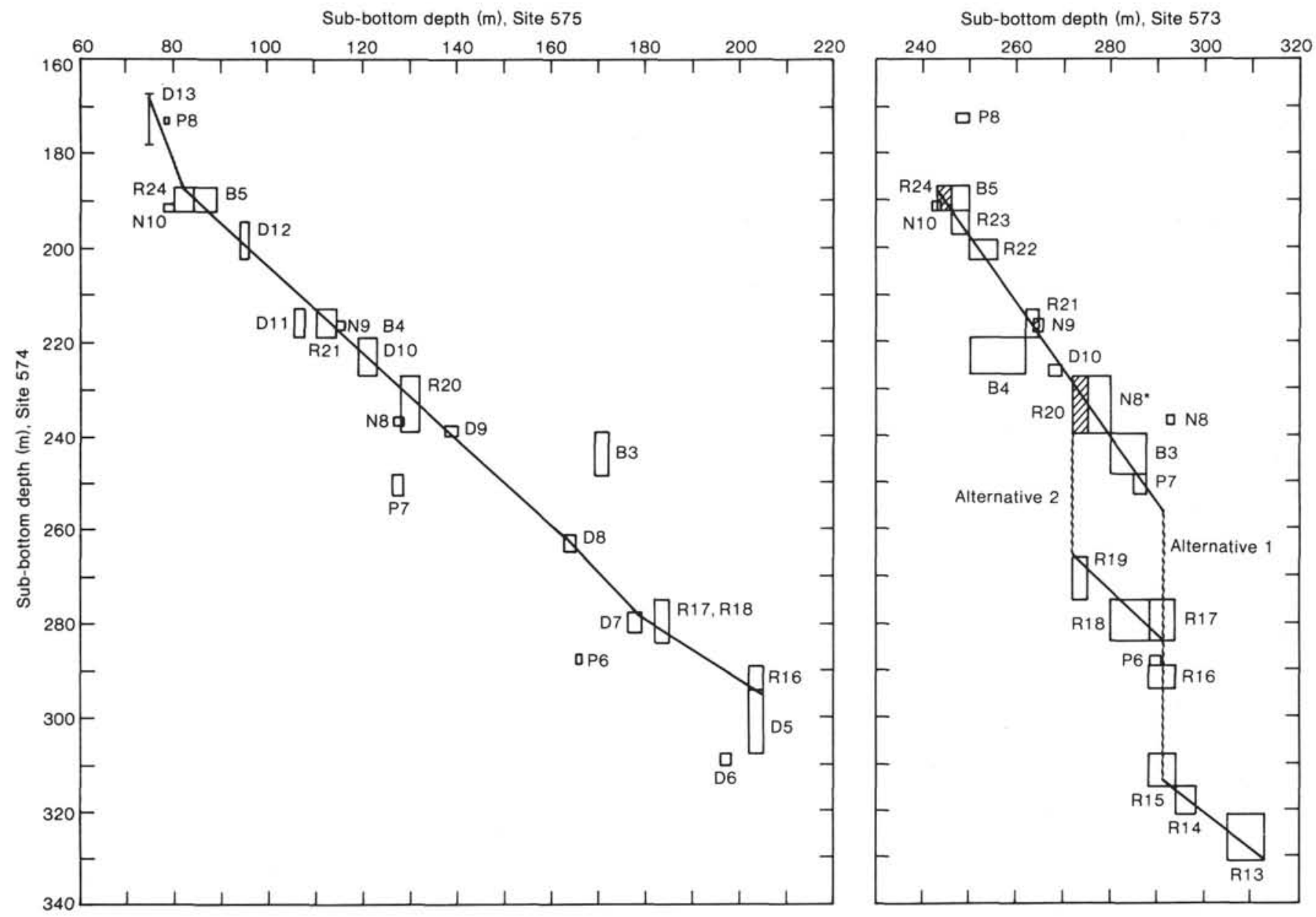

Figure 9. Graphic correlation of the lower Miocene sections at Sites 573, 574, and 575. See caption to Figure 8 for further explanation. The two alternatives for the Site 574-Site 573 correlation are discussed in the text. 
noted that the last occurrence of $T$. primalabiata at Site 575 seemed diachronous with correlations at Sites 574 and 71 , when compared with radiolarian stratigraphy. Discrepancies in site-to-site correlations of the N5/N6 boundary have been discussed earlier. The Leg 85 time scale (Fig. 2) suggests that the N4/N5 boundary (datum P6, 20.1 Ma) should lie stratigraphically higher at Site 574 if it is to be isochronous with correlations elsewhere. The correlation plot suggests about a 265 -m sub-bottom depth (Core 574C-8) for an isochronous placement of the N4/N5 boundary at Site 574 .

The two alternatives for correlation of the lower Miocene at Sites 573 and 574 (Fig. 9) both recognize a hiatus at about $290 \mathrm{~m}$ sub-bottom at Site 573 . A sharp lithologic contact at $290.6 \mathrm{~m}$ sub-bottom (uppermost Core 573B-17), between brown ooze (Subunit IIC) above and white-gray chalk (Subunit IID) below, is consistent with this interpretation.

One of the alternatives extends the upper Site 573Site 574 correlation line down through datums B3 and P7 and allows for one major hiatus (about 21.5 to $18.5 \mathrm{Ma}$ by extrapolation). The second alternative ignores events B3 and P7 (which were shown to be diachronous in the Site 574-Site 575 correlation) in favor of radiolarian datums R18 (the first occurrences of Didymocyrtis tubaria and D. violina) and R19 (the first occurrence of Siphostichartus corona), and suggests a second hiatus at about 272 m sub-bottom, between Cores 573B-14 and 573B-15. Under the second alternative, the older hiatus would be from about 21.5 to $20.5 \mathrm{Ma}$ and the younger hiatus would be from about 19.7 to $18.2 \mathrm{Ma}$. Barron (this volume) proposed a slightly younger hiatus within the middle of Core 573B-14.

Keller and Barron (1983) favor two such hiatuses (NH1a and NH1b) at nearby Site 77, but estimated ages for these hiatuses, 20.3 to $19.8 \mathrm{Ma}$ (NH1a) and 19.0 to $17.8 \mathrm{Ma}(\mathrm{NH} 1 \mathrm{~b})$ (ages adjusted by Barron et al., in press), differ somewhat for the age estimates at Site 573 . No lithologic changes are noted between Cores 573B-14 and $573 \mathrm{~B}-15$, but the preservation of diatoms deteriorates dramatically downhole at that level at Site 573. At present, the second alternative, with its two hiatuses, is favored over the first alternative with its single hiatus (Table 7).

\section{Middle Miocene to Uppermost Miocene}

Graphic correlation plots of the middle Miocene to uppermost Miocene sections of Sites 572, 573, and 573 are shown on Figure 10. Comparison of the Site 572 and Site 573 records (right side of the figure) suggests three hiatuses in the Site 573 section, at approximately $187 \mathrm{~m}$ (upper Core 573B-6), $177 \mathrm{~m}$ (lowermost Core 573B-5), and $158 \mathrm{~m}$ (uppermost Core 573B-3) sub-bottom depths (Table 7).

Barron (this volume) argues for the uppermost of these hiatuses, and estimates its age from 10.5 to $9.8 \mathrm{Ma}$. Pujos ("Cenozoic Nannofossils," this volume) also postulates a hiatus at about this interval in the lower part of the calcareous nannofossil CN8 Zone. Barron (this volume) notes that this hiatus (NH5 of Keller and Barron, 1983) coincides with the top of a distinctive purple- banded unit in Section 1 of Core 573B-3. At Site 574, Barron (this volume) recognized a coeval hiatus in lowermost Core 574-8 (about $70 \mathrm{~m}$ sub-bottom), where a purple-banded unit was also present. Pujos ("Cenozoic Nannofossils," this volume) also supports a hiatus in Zone CN8 at Site 574. The Site 573-Site 574 plot (left side of Fig. 10) shows that a section present at Site 573 has been removed at a hiatus at $70 \mathrm{~m}$ sub-bottom at Site 574 , implying that hiatus NH5 was of longer duration at Site 574 than at Site 573 . The additional interval removed at Site 574 has an estimated age of 11.1 to 10.5 Ma (Table 7).

Barron (this volume) notes compression in the agevs.-depth curve for Site 573 between 12.0 and $11.5 \mathrm{Ma}$, at about 174 to $176 \mathrm{~m}$ sub-bottom. At nearby Site 77, Barron (this volume) postulates a hiatus between 12.0 and $11.5 \mathrm{Ma}$, on the basis of the absence of a pronounced abundance peak in the diatom Denticulopsis hustedtii. Section equivalent to this middle hiatus at Site 572 (310 to $290 \mathrm{~m}$ sub-bottom) is characterized by very low percent carbonate values (site chapter), so that dissolution of carbonate at Site 573 may have been partly responsible for this hiatus. This middle hiatus correlates with widespread deep-sea hiatus NH4 of Keller and Barron (1983), which coincides with low values of percent carbonate throughout the equatorial Pacific (Barron and Keller, 1982). At this approximate interval, Mayer et al. (this volume) also note a sharp seismic boundary in sediments throughout the equatorial Pacific. The Site 573Site 574 plot (left side of Fig. 10) has not been drawn to show this hiatus, although the vertical distribution of the D19, N14, R35, and R36 datums could be construed to be consistent with existence of this hiatus at $177 \mathrm{~m}$ sub-bottom at Site 573 .

Evidence for the lowermost hiatus, which had an estimated duration of between 12.7 and $12.3 \mathrm{~m} . \mathrm{y}$., is less certain. Vertical distribution of the R33, R34, D17, N13, and D18 datums in both the Site $572-$ Site 573 plot and the Site 573-Site 574 plot support arguments for a hiatus at about $187 \mathrm{~m}$ sub-bottom at Site 573, although the hiatus is not plotted in the latter graph. No such hiatus at nearby Site 77 is suggested, however, by Keller (1980), Keller and Barron (1983), or Barron (this volume). Percent carbonate values within the equivalent interval ( 342 to $320 \mathrm{~m}$ sub-bottom) at Site $\mathbf{5 7 2}$ are typically high (site chapter). Hiatus NH3 of Keller and Barron (1983) (13.5 to $12.5 \mathrm{Ma}$ ) overlaps this lower hiatus only in part, and is typically older. No obvious lithologic changes are present in upper core 573B-6 at $187 \mathrm{~m}$ sub-bottom (site chapter)

During the middle Miocene, the section at Site 574 accumulated at a rate 1.5 to 1.2 times greater than the section at Site 573. During the late Miocene (after $10 \mathrm{Ma}$ ), however, the Site 573 section accumulated at a rate averaging 1.5 times the rate of accumulation at Site 574 . This reversal in relative rates reflects the northwestward movement of Sites 574 and 573 through the equatorial belt of high biologic productivity (Weinreich and Theyer, this volume).

The relative rates of sediment accumulation during the late middle Miocene to latest Miocene are generally 
A

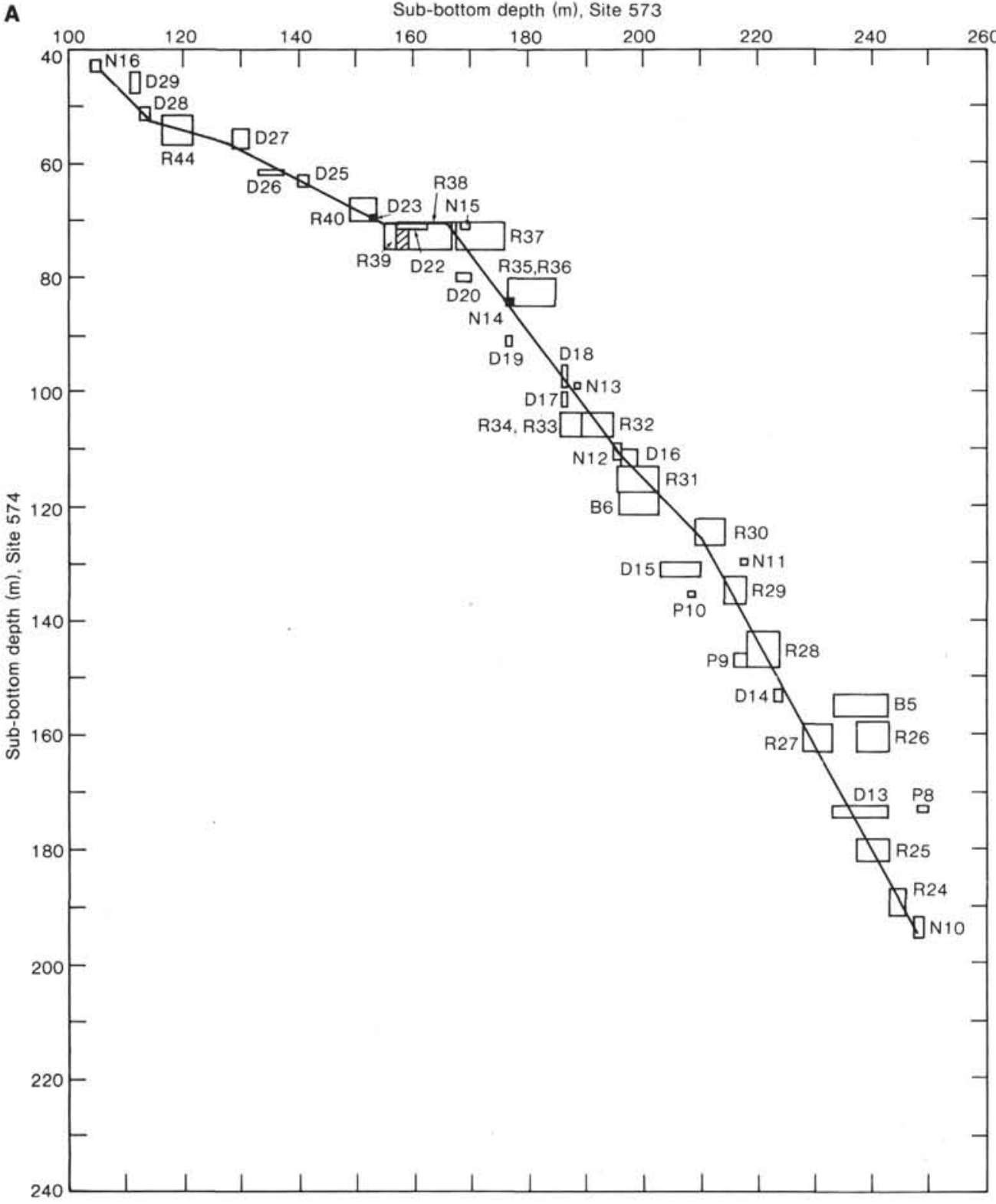

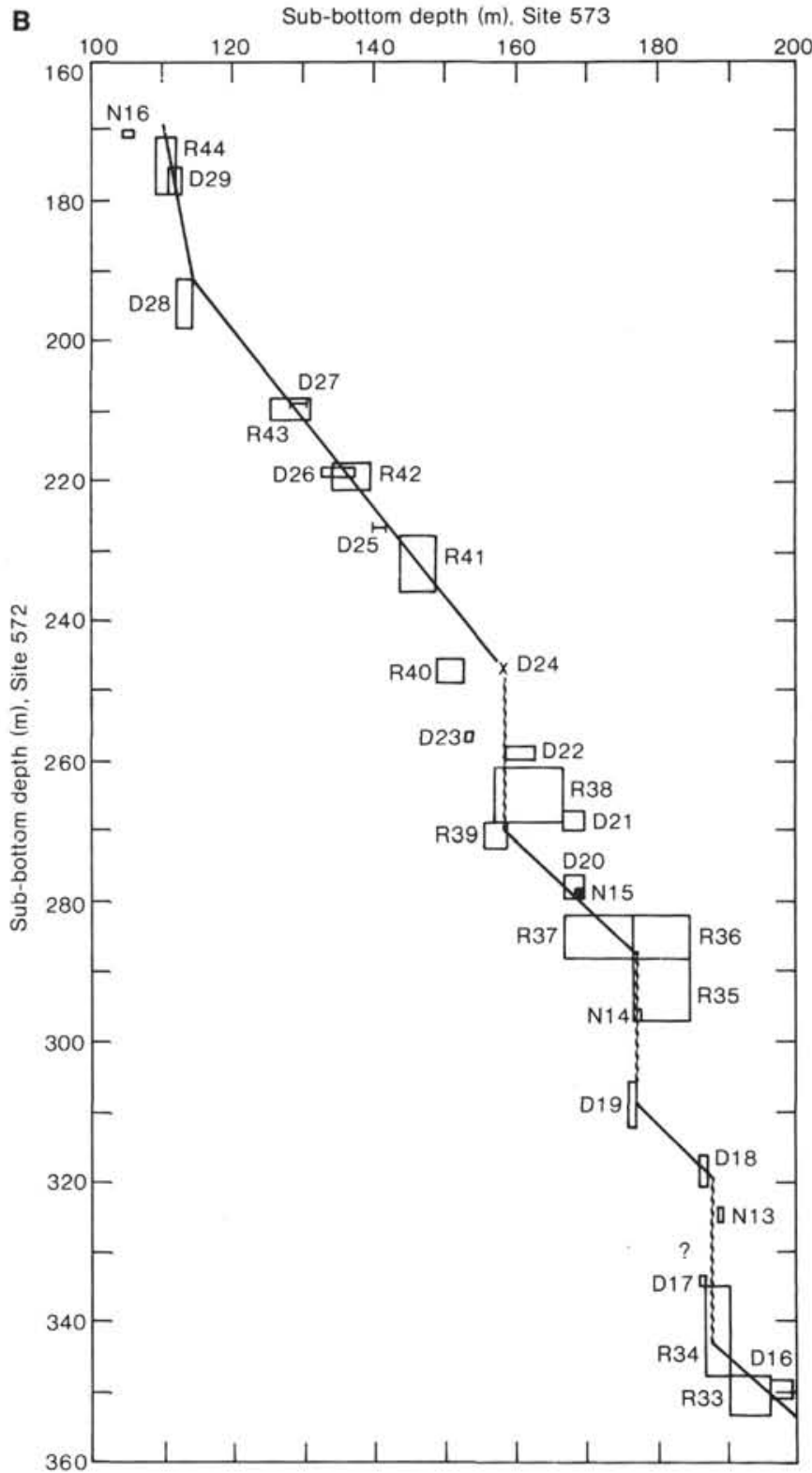

Figure 10. Graphic correlation of (A) the middle Miocene to uppermost Miocene sections at Sites 573 and 574 and (B) the upper middle Miocene to uppermost Miocene sections at Sites 572 and 573 . See caption to Figure 8 for further explanation. 
comparable between Sites 572 and 573, except during the three hiatus intervals at Site 573 (Fig. 10). After 6.3 Ma (datum D28), the accumulation rates at Site 572 appear to have been markedly higher than those at Site 573; this will be discussed in the following section on the uppermost Miocene through Quaternary graphic correlation plot.

As the plots are drawn, only datums P8 (the N8/N9 boundary), R26 (the last occurrences of the radiolarians Dorcadospyris dentata and Didymocyrtis violina), and B5 (the first occurrence of the benthic foraminifer Cibicidoides wuellerstorfi) lie appreciably off the correlation line between Sites 573 and 574. The N8/N9 boundary, however, was recognized by differing criteria (Saito, this volume) at Sites 573 and 574, namely, by the last occurrence of Globigerinoides sicanus at Site 573 and by the first occurrence of Orbulina suturalis, the zonal marker, at Site 574 .

\section{Uppermost Miocene through Quaternary}

Figure 11 is a graphic correlation plot of the sections at Sites 572 and 573 for the uppermost Miocene through the Quaternary. More detailed correlations of Leg 85 Quaternary sections by calcareous nannofossils and radiolarians are provided in the chapters by Pujos "Nannofossils from Quaternary Deposits," this volume) and Labracherie (this volume), respectively.

The section at eastern Site 572 accumulated at rates approximately twice as great as those at Site 573 during the latest Miocene (datum D29, or $6.2 \mathrm{Ma}$, to datum $\mathrm{N} 17$, or $5.1 \mathrm{Ma}$ ). The lowermost Pliocene (about 5.1 to 4.6 Ma), however, is extremely compressed at Site 573 , in that the interval between datums $\mathrm{N} 17$ (the CN9/CN10 boundary) and D35 (the first occurrence of Nitzschia jouseae) encompasses $25 \mathrm{~m}$ of section at Site 572 but only $6 \mathrm{~m}$ of section at Site 573 . On the basis of diatom stratigraphy, Barron (this volume) and Baldauf (this volume) argue for a hiatus between 5.1 and $4.6 \mathrm{Ma}$ (at the base of Core 573-9, about $76 \mathrm{~m}$ sub-bottom). They correlate this hiatus with widespread deep-sea hiatus $\mathrm{NH} 7$ of Keller and Barron (1983) (Table 7). As mentioned earlier, a more extensive hiatus at Site 575 has removed the section representing the interval between 5.1 and $3.4 \mathrm{Ma}$ (Fig. 7, Table 7).

Above this compressed interval at Site 573, accumulation rates at Site 572 remained greater than rates at Site 573 by a ratio of about $1.7: 1.0$ between 4.6 and 3.6 Ma (datums D35 to R51). The uppermost parts of Sites 573 and 572 , on the other hand, show nearly equivalent accumulation rates (compare also age-vs.-depth plots of Pujos, "Nannofossils from Quaternary Deposits," this volume, and Baldauf, this volume). The brief hiatus (about 2.2 to $1.8 \mathrm{Ma}$ ) predicted by diatoms at about $33 \mathrm{~m}$ sub-bottom at Site 572 (Core 572A-4) (Barron, this volume; Baldauf, this volume) is not apparent in Figure 11, so it is possible that between Sites 572 and 573 some diachrony exists between the ages of the last occurrence of Thalassiosira convexa (D40) and the first occurrence of Pseudoeunotia doliolus (D41).

Of the 37 latest Miocene through Quaternary datum levels correlated between Sites 572 and 573, all but three lie on the plotted correlation line (Fig. 11). Those three aberrant datums include the first occurrence of the radiolarian Pterocanium prismatium (R48) and the last occurrences of the diatoms Asterolampra acutiloba (D33) and Thalassiosira miocenica (D34). Nigrini (this volume) notes that $P$. prismatium is rare at the lower end of its range, so its first occurrence may actually be lower at Site 573 than what has been plotted on Figure 11. It is possible that the diatoms A. acutiloba and T. miocenica are reworked slightly upsection at Site 573 .

\section{AGE-VS.-DEPTH PLOTS}

The graphic correlation plots (Figs. 8 to 11) show which of the Leg 85 sections are the most complete for any interval of time between the latest Eocene and the Quaternary. In addition, diachronous occurrences of datum levels have been noted and the sequencing of the various microfossil datum levels has been established.

On Figure 12, age-vs.-depth graphs for the middle Miocene through Quaternary of Site 572 and a composite section from Sites 573 and 574 have been constructed using the published age estimates for the various datum levels shown on Tables 2 to 6 . A composite section consisting of the Quaternary through upper Miocene of Site 573 and the middle Miocene of Site 574 is plotted, because the younger section at Site 574 is compressed (Fig. 5) and the middle Miocene of Site 573 apparently contains two hiatuses (Fig. 10). Both Site 573 and Site 574 have a hiatus between about 10.5 and $9.8 \mathrm{Ma}$ (NH 5) (Table 7).

The Site 572 plot shows high rates of sediment accumulation (about $50 \mathrm{~m} / \mathrm{m}$.y.) in the middle Miocene between 15.0 and $11.0 \mathrm{Ma}$ and across the Miocene/Pliocene boundary between 6.3 and $3.8 \mathrm{Ma}$. Lower rates (about $16 \mathrm{~m} / \mathrm{m} . \mathrm{y}$.) characterized most of the late Miocene (11.1 to 6.3 Ma) and the late Pliocene through Quaternary $(3.8$ to $0 \mathrm{Ma})$.

Middle Miocene accumulation rates at Site 574 were also relatively high, averaging $26 \mathrm{~m} / \mathrm{m}$.y. between 15.5 and 11.1 Ma. Rates during the late Miocene interval from 9.8 to $6.3 \mathrm{Ma}$ were about $12 \mathrm{~m} / \mathrm{m}$.y. at Site 573 . As at Site 572, accumulation rates returned to middle Miocene values $(26 \mathrm{~m} / \mathrm{m} . \mathrm{y}$.) across the Miocene/Pliocene boundary between 6.3 and $3.5 \mathrm{Ma}$. An exception is a compressed interval or hiatus between 5.1 and $4.6 \mathrm{Ma}$ at Site 573. Late Pliocene through Quaternary accumulation rates at Site 573 were about $14 \mathrm{~m} / \mathrm{m}$.y., or nearly equal to accumulation rates at Site $572(16 \mathrm{~m} / \mathrm{m}$.y.).

Of the datums plotted on Figure 12, only R30, the first occurrence of the radiolarian Diartus petterssoni, lies appreciably off the age-vs.-depth plot. The diachrony of this datum, which corresponds to the Dorcadospyris alata/Diartus petterssoni boundary, has been discussed earlier.

On Figure 13, age-vs.-depth plots for the lower Miocene of Site 575 and the lower Miocene to upper Eocene of Site 574 have been constructed. As mentioned earlier, the Paleogene section at Site 573 contains two hiatuses and one compressed interval (possibly a hiatus), so it was not plotted.

Between 37.0 and $35.0 \mathrm{Ma}$ and between 34.6 and $30.7 \mathrm{Ma}$, accumulation rates at Site 574 were approxi- 


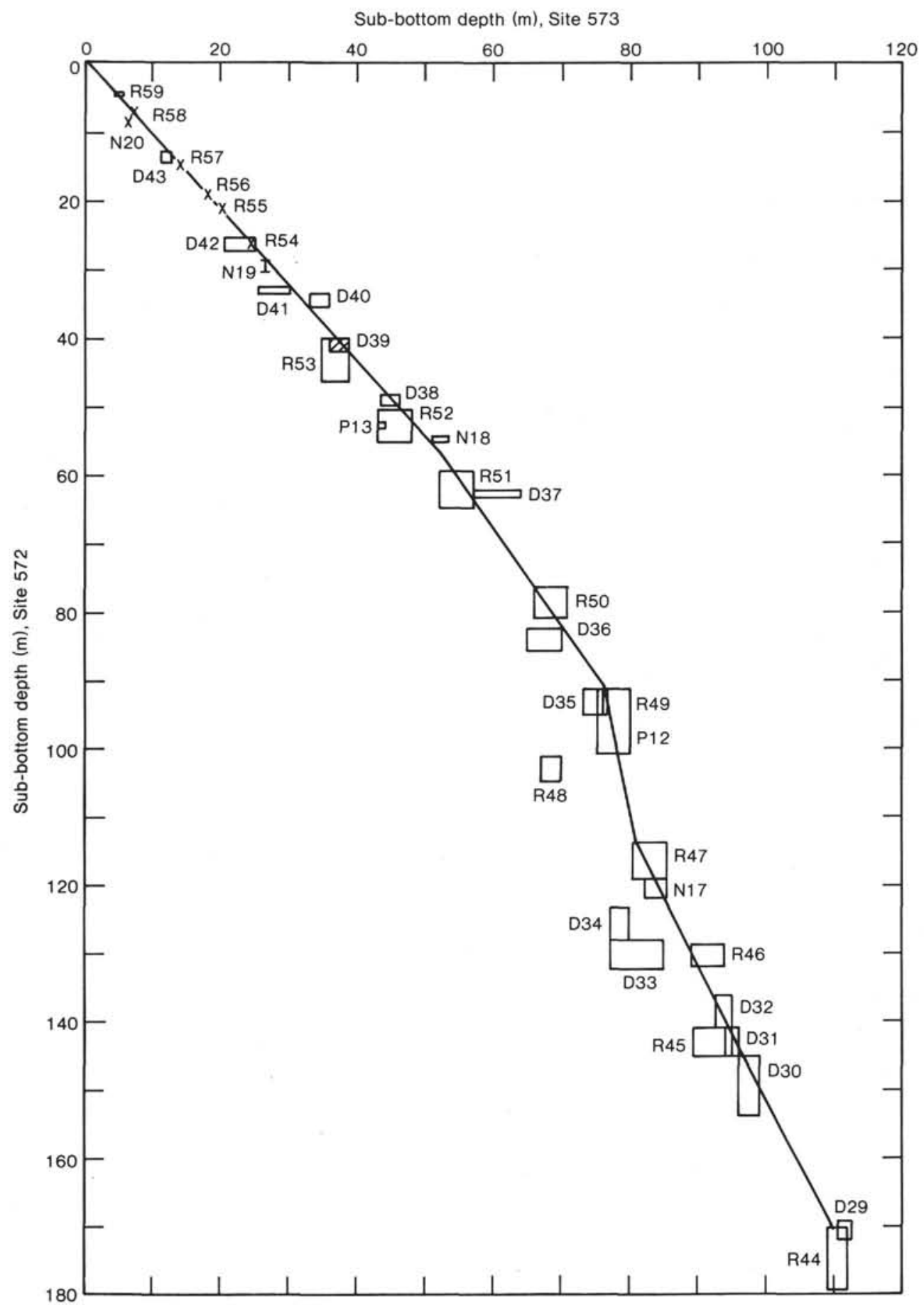

Figure 11. Graphic correlation of the uppermost Miocene through Quaternary sections at Sites 572 and 573. See caption to Figure 8 for further explanation.

mately $12 \mathrm{~m} / \mathrm{m} . y$. A brief interval from 35.1 to $34.6 \mathrm{Ma}$, however, corresponding to calcareous nannofossil Subzone CP16c, according to both Pujos and Gartner and Chow (Fig. 5), apparently accumulated at very high rates approaching $60 \mathrm{~m} / \mathrm{m}$.y. It is possible that these anomalously high accumulation rates are an artifact of the time scale, but both Berggren, Kent, and Flynn (in press) and Bukry (1975) independently estimate a duration of only $0.5 \mathrm{~m}$.y. for Subzone CP16c. Further complicating the picture is the coincidence of relatively low percent carbonate values (60 to $80 \%$ vs. typical Oligocene values of $90 \%$ ) (site chapters) with Subzone CP16c at both Site 573 and Site 574 . No explanation can presently be given for these high accumulation rates, but it should be noted that Keigwin (1980), Keller (1983 a, b), and Keigwin and Keller (1984) report that benthic foraminiferal oxygen isotopes at Pacific Sites 77, 277, and 292 and Atlantic Site 563 show their highest positive early Oligocene values (cooling) in Subzone CP16c or its equivalent. 


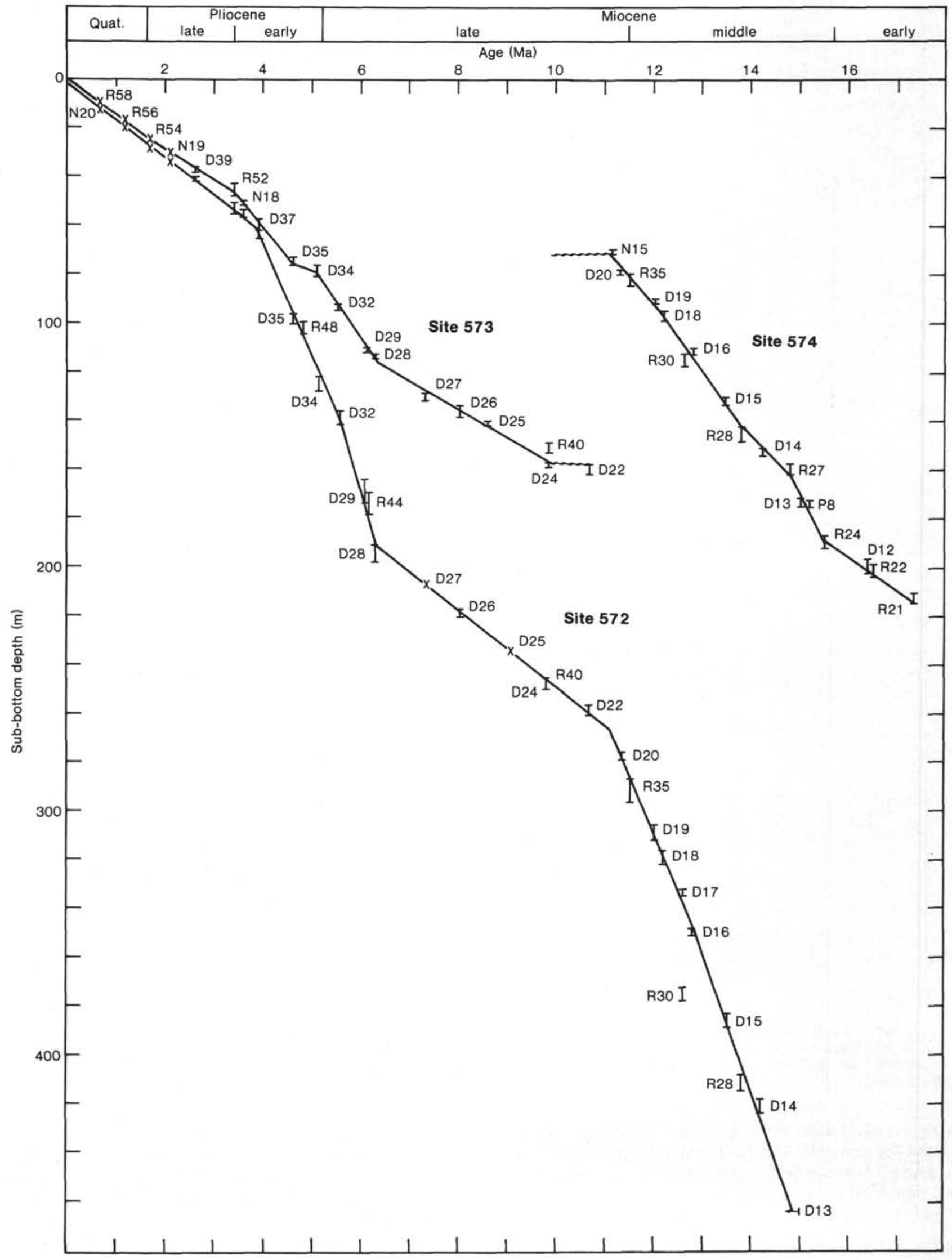

Figure 12. Age-vs.-depth plots for the Quaternary through middle Miocene at Site 572 and a composite section from Site 573 (Quaternary through late Miocene) and Site 574 (middle Miocene). Microfossil datums from Tables 2 to 5 , for which absolute age estimates exist, have been used to construct the plots. 


\section{J. A. BARRON ET AL.}

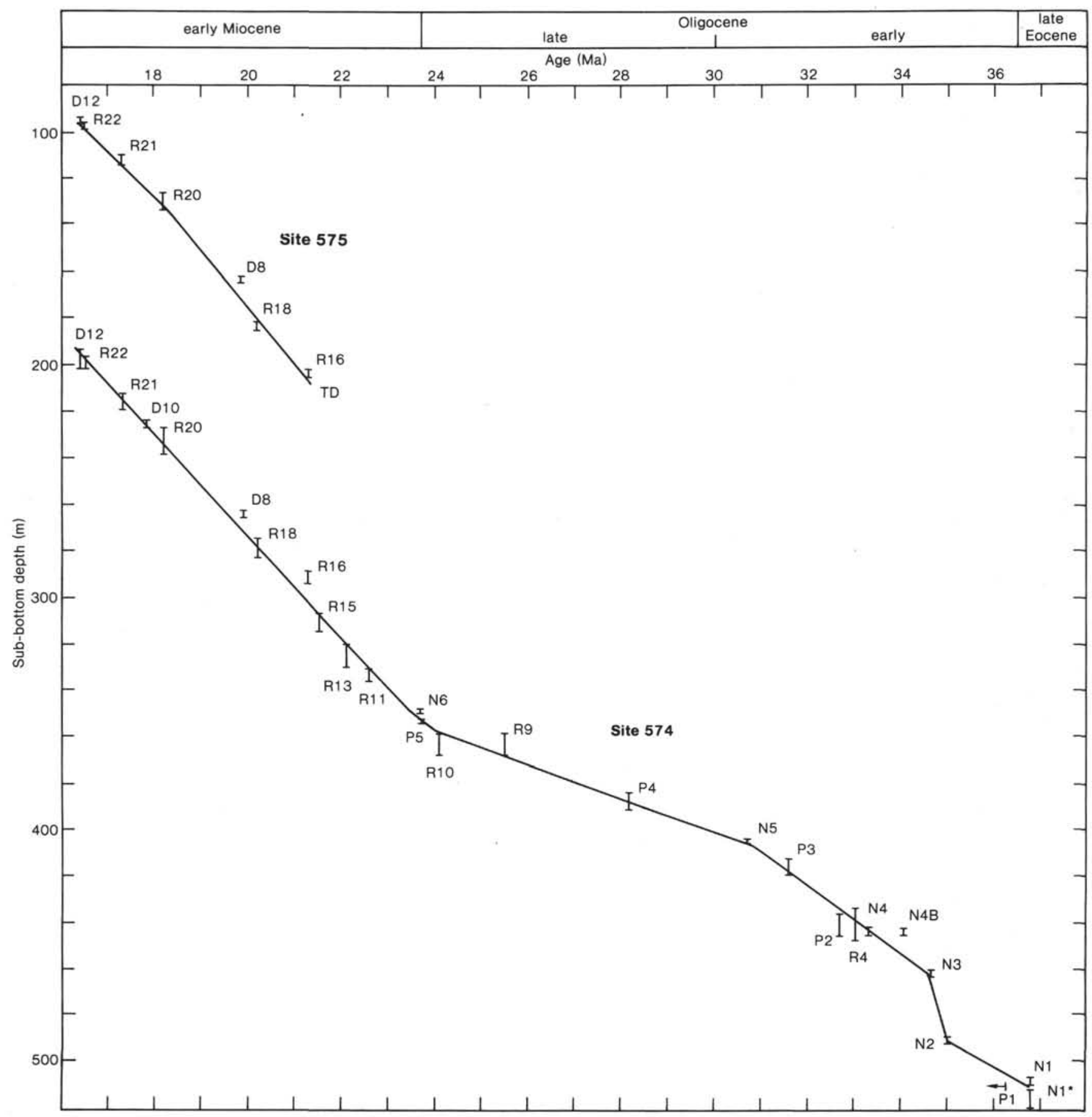

Figure 13. Age-vs.-depth plots for the early Miocene at Site 575 and the early Miocene to late Eocene at Site 574. Microfossil datums from Tables 2 to 5 , for which absolute age estimates exist, have been used to construct the plots. N4B refers to the age correlation (34.1 Ma) by Berggren et al. (in press) for the CP17/CP18 calcareous nannofossil zonal boundary. Asterisk denotes calcareous nannofossil datums after Gartner and Chow (this volume).

Low accumulation rates of about $7 \mathrm{~m} / \mathrm{m} . \mathrm{y}$. during the late Oligocene ( 30.7 to $24.0 \mathrm{Ma}$ ) are implied for Site 574. Early Miocene accumulation rates, on the other hand, increased to 20 to $25 \mathrm{~m} / \mathrm{m}$.y. at both Site 574 and Site 575 (Fig. 13).

\section{Significance of Accumulation Rates}

In the central equatorial Pacific, the present-day zone of high primary productivity extends from about $3-4^{\circ} \mathrm{S}$ to about $0-1^{\circ} \mathrm{N}$, at $145^{\circ}$ to $120^{\circ} \mathrm{W}$, and from about $5^{\circ} \mathrm{S}$ to about $5^{\circ} \mathrm{N}$, between $120^{\circ}$ and $105^{\circ} \mathrm{W}$ (Koblentz-Mishke et al., 1970). Backtracking of the Leg 85 sites according to the model of van Andel et al. (1975) (see Theyer et al., this volume) can be used to suggest the interval of time during which the Leg 85 sites lay beneath waters of high biologic productivity (assuming no major change in the position of that productivity zone with respect to the equator). Such an exercise yields the following resi- 
dence times for the Leg 85 sites within the equatorial Pacific high-productivity zone: Site 572,0 to $15 \mathrm{Ma}=$ entire record; Site 573,0 to $10 \mathrm{Ma}$; Site 574,12 to 25 $\mathrm{Ma}$; and Site 575,16 to $35 \mathrm{Ma}$.

To a large extent, comparison of the relative sediment accumulation rates in the graphic correlation plots (Figs. 8 to 11 ) and age-vs.-depth plots (Figs. 12,13) reflects this model, in that the highest relative accumulation rates correspond to those intervals deposited beneath the highproductivity zone. Consequently, Site 574 had higher accumulation rates than Site 573 during the middle Miocene, whereas the opposite relationship was true during the late Miocene (Fig. 10). Accumulation rates at eastern Site 572, however, were typically always higher than rates at the western sites (Fig. 12), attesting to the higher primary productivity in the eastern equatorial Pacific (Koblentz-Mishke et al., 1970).

During the late Oligocene, Site 573 lay farther south of the equator $\left(7\right.$ to $\left.8^{\circ} \mathrm{S}\right)$ than Site $574\left(3\right.$ to $\left.4^{\circ} \mathrm{S}\right)$, yet accumulation rates at Site 573 were typically twice those at Site 574 (Fig. 8). This contradiction of the model may result from enhanced carbonate preservation at Site 573, since upper Oligocene percent carbonate values at Site 573 are on the average slightly higher than those at Site 574 (site chapters). The water depth at Site 574 was probably slightly greater than that at Site 573 during the late Oligocene, because the present-day water depths of Sites 574 and 573 are 4560 and $4300 \mathrm{~m}$, respectively. During the earliest Oligocene ( 34.6 to $36.5 \mathrm{Ma}$, below datum N3), accumulation rates at Sites 573 and 574 were about equal (Fig. 8), indicating that the two sites experienced similar levels of productivity (see also Theyer et al., this volume).

\section{Extrapolation of Ages for Datum Levels}

If the age-vs.-depth plots (Figs. 12,13) are considered accurate, then one can use them to extrapolate absolute age estimates for those datums which have not been calibrated directly to paleomagnetic stratigraphy. This exercise has been done in Tables 2 to 6 (right-hand column). The age ranges given for the individual datums reflect the constraints of their plotted values on the graphs. In making these determinations, uniform accumulation rates between those datums with published absolute ages are assumed unless hiatuses are predicted on the graphic correlation plots (Figs. 8 to 11 ). The extrapolated absolute ages differ in some cases from published age estimates (compare columns on Tables 2 to 6 ). These differences may reflect differences in taxonomic interpretations between workers, differences in the accuracy of the extrapolations, or true diachrony in species ranges.

\section{SUMMARY}

A major objective of DSDP Leg 85 was to recover relatively undisturbed hydraulic piston cores within the high-productivity zone of the central equatorial Pacific. Earlier drilling during Legs 5, 8, 9, and 16 produced rotary-drilled cores which have been of key importance in developing biochronologies for the Oligocene through Quaternary, and which have been a focus for low-latitude Pacific paleoceanographic studies (van Andel et al.,
1975; Keller and Barron, 1983). Hydraulic piston coring in this area would allow the development of high-resolution bio-, magneto-, seismic-, carbonate, and stable-isotope stratigraphies, needed for determining the sequencing and mechanisms of paleoceanographic changes.

During Leg 85, hydraulic piston cores were recovered at five sites which form an east-west transect from $114^{\circ} \mathrm{W}$ (Sites 571,572 ) to $133-135^{\circ} \mathrm{W}$ (Sites 573 to 575 ) and a south-north transect across the high-productivity zone from $0^{\circ} \mathrm{N}$ (Site 573) to $6^{\circ} \mathrm{N}$ (Site 575). At each of the four main sites (572 to 575 ), duplicate hydraulic piston cores were collected through the Quaternary and Pliocene and into successively older (deeper) levels of the Miocene: at Site 572, to $6.2 \mathrm{Ma}$; at Site 573, to $10 \mathrm{Ma}$; at Site 574 , to $16.7 \mathrm{Ma}$; and at Site 575 , to $22 \mathrm{Ma}$.

Paleomagnetic stratigraphy was obtained for the Quaternary through late Pliocene at Site 573, for the Quaternary to late Miocene at Site 574 , and for the Quaternary to late middle Miocene plus an interval within the late early Miocene (18.2 to $16.4 \mathrm{Ma}$ ) at Site 575 . At Site 575 , for the first time, many microfossil datums were calibrated directly to the interval from the upper part of paleomagnetic Chron 17 to the middle part of paleomagnetic Chron 16.

At eastern Site 572, a complete sequence apparently free of hiatuses was cored through the Quaternary to the lower middle Miocene (about $15 \mathrm{Ma}$ ). High sediment accumulation rates (about $50 \mathrm{~m} / \mathrm{m}$.y.) characterize the middle Miocene (15 to $11 \mathrm{Ma}$ ) and uppermost Miocene to lower Pliocene (6.3 to $3.8 \mathrm{Ma}$ ), and diatoms typically are the dominant microfossils.

At Site 573, about $10 \mathrm{~km}$ from Site 77, Quaternary to upper Eocene sediment was cored in three holes. Numerous short to medium-length hiatuses are present at Site 573, including hiatuses at the Eocene/Oligocene, Oligocene/Miocene, middle Miocene/upper Miocene, and (possibly) at the Miocene/Pliocene boundaries (Table 7). Most of these hiatuses have been earlier postulated to exist at nearby Site 77, but they are confirmed at Site 573 by graphic correlation plots with the other Leg 85 sections.

A complete sequence through the Eocene/Oligocene boundary was obtained at Site $574\left(4^{\circ} \mathrm{N}\right)$, as was a thick reference section for the middle Miocene through Oligocene. An early late Miocene hiatus (11.1 to $9.8 \mathrm{Ma}$ ) (Table 7) is represented at the site, and the upper Miocene through Quaternary section is compressed relative to that at Site $573\left(0^{\circ} \mathrm{N}\right)$.

At Site $575\left(6^{\circ} \mathrm{N}\right)$, coring was terminated in the lower Miocene (about $22 \mathrm{Ma}$ ) owing to lack of ship time. Nevertheless, a thick lower Miocene section free of hiatuses was recovered at the site. Two hiatuses in the early late Miocene $(10.5$ to $9.8 \mathrm{Ma})$ and early Pliocene $(5.1$ to $3.4 \mathrm{Ma}$ ) are recorded in the relatively compressed upper section at Site 575 (Table 7).

Throughout the Leg 85 sequences, planktonic foraminiferal, calcareous nannofossil, radiolarian, and diatom stratigraphies are typically consistent with one another and with the Leg 85 biostratigraphic time scale. Most of the few discrepancies that exist can be explained by diachronous species ranges, reworking, or differences 
in taxonomic concepts between workers. Graphic correlation plots between the sequences are especially helpful in identifying diachronous datums, and can also be used to check the isochrony of benthic foraminiferal datum levels.

Age-vs.-depth plots have been constructed using datums with published absolute age estimates, and ages of other datums have been extrapolated from the plots. In some cases the extrapolated age estimates differ from published age estimates, but usually they agree to within 100,000 to 200,000 yrs.

The biostratigraphic studies discussed in this chapter certainly can be refined by closer sampling intervals and by quantitative studies (see Pujos, and Baldauf, both this volume). Detailed carbonate and stable-isotope studies, such as those by Pisias and Prell (this volume) and Pisias and Shackleton (this volume), allow even greater refinement of time in the hydraulic piston cores. The sediment sequences recovered during Leg 85 are excellent for such high-resolution studies, and will undoubtedly provide a focal point for future paleoceanographic studies in the central equatorial Pacific.

\section{ADDENDUM}

Since 1974 it has widely been accepted that paleomagnetic Anomaly 5 correlates with paleomagnetic Chron 9 as recognized in the sediment (Berggren and Van Couvering, 1974; Theyer and Hammond, 1974; Ryan et al., 1974). As discussed by Theyer and Hammond (1974), Foster and Opdyke's (1970) correlation of Anomaly 5 with Chron 11 was rejected, because biostratigraphic and radiometric calibrations of the middle Miocene/upper Miocene boundary were in better agreement with an Anomaly 5-Chron 9 correlation. Berggren and Van Couvering (1974) and Ryan et al. (1974) all presented arguments, based on available radiometric evidence, that the middle/upper Miocene boundary must be older than the base of Anomaly 5 (about 10.2 to $10.4 \mathrm{Ma}$ ). At the same time, Berggren and Van Couvering (1974) and Ryan et al. (1974) all showed that middle Miocene microfossils ranged into lower paleomagnetic Chron 11 or higher, so it seemed impossible that Anomaly 5 could correlate with Chron 11.

Recently, however, W. A. Berggren (pers. comm., 1984; and Berggren, Kent, and Van Couvering, in press) has suggested that Anomaly 5 does indeed correlate with Chron 11 (as it has been recognized in the sediment), and that earlier radiometric calibrations of the middle/ upper Miocene boundary are in error. Berggren cited paleomagnetic-biostratigraphic correlations at DSDP Site 519 in the South Atlantic by Poore et al. (1984) and Hsü et al. (1984). Site 519 was drilled on crust slightly older than Anomaly 5, and middle Miocene calcareous nannofossils (Zones CN6 and CN7) were recorded within a relatively long $(10 \mathrm{~m})$ normally polarized interval immediately above basement. Because correlations of $\mathrm{CN} 6$ and CN7 ( = NN8 and NN9) calcareous nannofossils with paleomagnetic Chron 11 have been well established (Ryan et al., 1974; Berggren and Van Couvering, 1978; Keller et al., 1982; Barron et al., in press), it seems apparent that the normal interval containing $\mathrm{CN} 6$ and $\mathrm{CN} 7$ calcareous nannofossils at Site 519 correlates with both Anomaly 5 and Chron 11 (Hsü et al., 1984).

The Leg 85 biostratigraphic time scale (Fig. 2) incorporates an Anomaly 5-Chron 9 correlation, as do the various chapters of this volume. The purpose of this addendum is to present the alternative middle to late Miocene biostratigraphic time scale based on an Anomaly 5-Chron 11 correlation (compare Berggren, Kent, and Van Couvering, in press), so that readers favoring such a correlation can reassign absolute ages to middle and late Miocene intervals discussed in the Leg 85 chapters.

Figure 14 shows reassignment of paleomagnetic Chrons 7 through 14 to the polarity sequence between Anomalies $3 \mathrm{~A}$ and $5 \mathrm{~B}$, based on an Anomaly 5-Chron 11 correlation. W. A. Berggren (pers. comm., 1984) feels that the correlation of the chrons above Chron 7 and below Chron 14 with the paleomagnetic time scale proposed by Ryan et al. (1974) and LaBrecque et al. (1977) (and adopted in the Leg 85 biostratigraphic time scale) does not require adjustment. The adopted correlation (Fig. 14) largely follows alternative " $\mathrm{A}$ " of Theyer and Hammond (1974). It could be argued that this older numbering system of chrons (Ryan et al., 1974; LaBrecque et al., 1977) should be abandoned in favor of a newer system proposed by Tauxe et al. (1983). Tauxe et al. (1983) label successive chrons, from the top of one numbered anomaly to the top of the next oldest numbered anomaly, with the same number as the included anomaly, and preface those numbers with a "C." Such a numbering system is also shown on Figure 14, and has been incorporated in the Paleogene part of Figure 2. Earlier published paleomagnetic correlations of microfossil datum levels refer, however, almost exclusively to the older system of numbering chrons, so much of the following discussion will utilize that system.

Correlation of the microfossil zones and subzones with the paleomagnetic chrons on Figure 14 differs little from the correlation shown on Figure 2, but the new anomaly-chron correlation results in changes in the estimated absolute ages of the microfossil zones and subzones (Figs. 2, 14). This correlation has been accomplished by reassigning absolute ages to the middle and late Miocene microfossil datum levels, which have been directly calibrated with paleomagnetic stratigraphy (Table 8 ) on the basis of the Anomaly 5-Chron 11 correlation model of Figure 14. Absolute ages of additional datum levels (and zonal boundaries) have been extrapolated from replotted age-vs.-depth curves for Sites 572 to 574 (Fig. 15) in the manner used to extrapolate absolute ages on Tables 2 to 6 . Thus, the age of the middle Miocene/upper Miocene boundary changes from about $11.5 \mathrm{Ma}$ to about 9.5 Ma when an Anomaly 5-Chron 11 correlation is adopted (Fig. 14).

It is immediately apparent that the new age-vs.-depth curves for Sites 572 to 574 (Fig. 15) differ considerably from those of Figure 12, in that no kink of low sediment accumulation rates occurs in the new plots between 11 and 6.2 Ma. As stated earlier, Sites 572 and 574 probably lay within the equatorial region of highest productivity during the entire late Miocene, and it is difficult to explain why sediment accumulation rates would have 


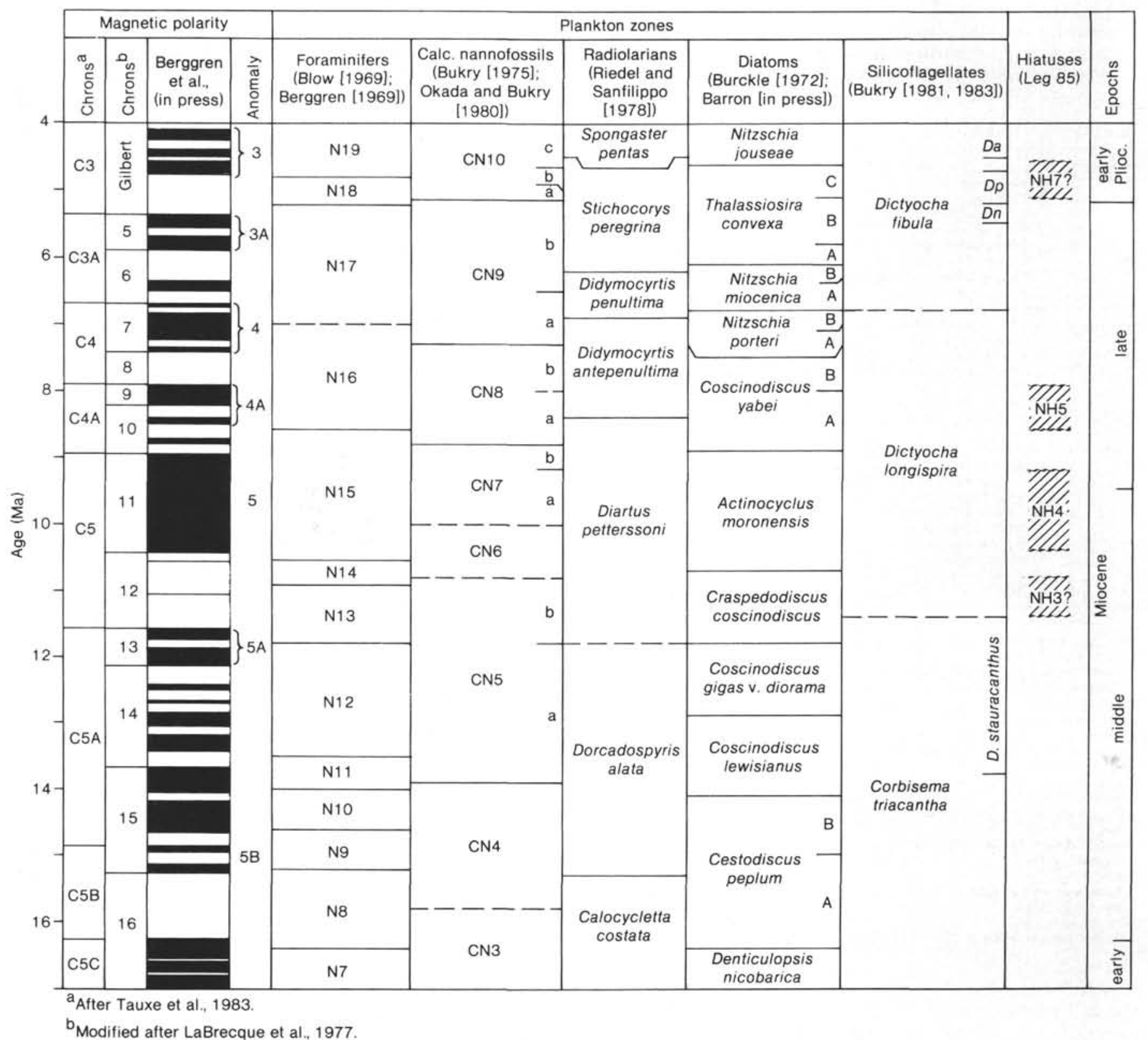

Figure 14. Alternative biostratigraphic time scale for the middle and late Miocene, based on a correlation of paleomagnetic Anomaly 5 with paleomagnetic Chron 11. See caption to Figure 2 for further explanation.

dropped sharply between 11 and $6.2 \mathrm{Ma}$. As the replotted curves of Figure 15 show no such drop in sediment accumulation rates between 11 and $6.2 \mathrm{Ma}$ at Sites 572 and 574 , but rather show relatively constant rates (about 25 to $30 \mathrm{~m} / \mathrm{m}$.y. at Site 572 and about 14 to $18 \mathrm{~m} / \mathrm{m}$.y. at Site 574), they both add support to the Anomaly 5Chron 11 correlation of Figure 14.

It should also be noted that the ages and durations of hiatuses $\mathrm{NH} 3, \mathrm{NH} 4$, and $\mathrm{NH} 5$ are changed by an Anomaly 5-Chron 11 correlation (Figs. 14, 15). In Leg 85 sediment, hiatus $\mathrm{NH} 3$ ranges from 11.5 to $10.7 \mathrm{Ma}$, hiatus NH4 ranges from 10.4 to $9.2 \mathrm{Ma}$, and hiatus NH5 ranges from 8.6 to $7.9 \mathrm{Ma}$ (8.8 to $7.9 \mathrm{Ma}$ at Site 574) (Figs. $14,15)$.

Extrapolations by Weinreich and Theyer (this volume) for Site 574 also reinforce an Anomaly 5-Chron 11 cor- relation. As stated earlier, Weinreich and Theyer (this volume) recognize the top of a long, normally polarized interval at about $79 \mathrm{~m}$ sub-bottom in lower Core 574-9, which they extrapolate to be the top of Anomaly 5 (about $8.9 \mathrm{Ma})$. Microfossils within this interval $(\mathrm{CN} 7$ calcareous nannofossils, Diartus petterssoni Zone radiolarians, and Actinocyclus moronensis Zone diatoms) suggest, however, a Chron 11 assignment (Figs. 2, 5). Correlation of Anomaly 5 ages (10.42 to $8.92 \mathrm{Ma}$ ) with Chron 11 would eliminate this apparent discrepancy.

Finally, a brief review of the literature reveals that radiometric and paleomagnetic calibrations of the last occurrence of the radiolarian Cyrtocapsella japonica at DSDP South Atlantic Sites 512 and $513\left(50^{\circ} \mathrm{S}\right)$ (Ciesielski, 1983) also lend support for an Anomaly 5-Chron 11 correlation. Ciesielski (1983) shows that at Site 512 
Table 8. Middle and late Miocene microfossil datum levels directly correlated with paleomagnetic stratigraphy and estimated absolute ages based on the correlation model of paleomagnetic Anomaly 5 with paleomagnetic Chron 11 (Fig. 14).

\begin{tabular}{|c|c|c|c|}
\hline Event $^{a}$ & Datum $^{b}$ & Paleomagnetic correlation & $\begin{array}{l}\text { Age } \\
(\mathrm{Ma})\end{array}$ \\
\hline D29 & Thalassiosira miocenica & Uppermost Chron 6 & $6.1_{d}^{c}$ \\
\hline R44 & $\begin{array}{l}\text { Stichocorys delmontensis } \\
\quad \rightarrow \text { S. peregrina }\end{array}$ & Uppermost Chron 6 & $6.2^{\mathrm{d}}$ \\
\hline D28 & B. Thalassiosira praeconvexa & Upper Chron 6 & $6.3^{\mathrm{c}}$ \\
\hline $\mathrm{Np}$ & Amaurolithus primus & Rev. event, Chron 6 & $6.5^{\mathrm{e}}$ \\
\hline D27 & Nitzschia miocenica & Upper Chron 7 & $6.8^{\mathrm{c}}$ \\
\hline D26 & Thalassiosira burckliana & Middle Chron 7 & $7.0^{\mathrm{c}}$ \\
\hline N17 & Discoaster quinqueramus & Lowermost Chron 7 & $7.3^{\mathrm{e}}$ \\
\hline D25 & Coscinodiscus plicatus & Lowermost Chron 7 & $7.3^{f}$ \\
\hline R40 & Didymocyrtis penultima & Uppermost Chron 9 & $7.9^{\mathrm{d}}$ \\
\hline D23 & Thalassiosira burckliana & Uppermost Chron 9 & $8.0^{\mathrm{c}}$ \\
\hline $\mathrm{Pa}$ & Neogloboquadrina acostaensis & Middle Chron 10 & $8.6^{\mathrm{g}, \mathrm{h}}$ \\
\hline N15 & Discoaster hamatus & Lower rev, event, Chron 10 & $8.8^{\mathrm{h}}$ \\
\hline D20 & Actinocyclus moronensis & Lowermost Chron 10 & $8.9^{c}$ \\
\hline R37 & Cyrtocapsella japonica & Uppermost Chron 11 & $9.1^{\mathrm{g}, \mathrm{i}}$ \\
\hline $\mathrm{Nc}$ & Catinaster calyculus & Upper Chron 11 (Anom. S) & $9.2^{j}$ \\
\hline D19 & Coscinodiscus tuberculatus & Lowermost Chron 11 & $10.4^{k}$ \\
\hline Ps & Globorotalia siakensis & Uppermost Chron 12 ? & $10.6^{8}$ \\
\hline D18 & Craspedodiscus coscinodiscus & Upper Chron 12 & $10.7^{8}$ \\
\hline $\mathbf{R t}$ & Cyrtocapsella tetrapera & Lowermost Chron 12 & $11.4^{i}$ \\
\hline $\mathbf{R j}$ & Cyrtocapsella japonica & Lower Chron 13 & $12.0^{1}$ \\
\hline D15 & Coscinodiscus lewisianus & 2nd normal above Chron 15 & $12.9^{\mathrm{c}}$ \\
\hline R28 & Didymocyrtis taticonus & Uppermost Chron 15 & $13.8^{\mathrm{d}}$ \\
\hline D14 & Cestodiscus peplum & Top rev, event, Chron 15 & $14.1^{\mathrm{c}}$ \\
\hline $\mathrm{Rc}$ & Calocycletta costata & 3rd normal, Chron 15 & $14.9^{\mathrm{d}}$ \\
\hline D13 & Annellus californicus & Lower rev. event, Chron 15 & $15.0^{\mathrm{C}}$ \\
\hline D12 & Cestodiscus peplum & Upper normal, Chron 16 & $16.4^{1}$ \\
\hline R22 & Giraffospyris toxaria & Upper normal, Chron 16 & $16.5^{I}$ \\
\hline R21 & Calocycletta costata & Lower Chron 16 & $17.3^{1}$ \\
\hline
\end{tabular}

Note: All correlations made from original paleomagnetic stratigraphy with chrons labeled as in Figure 14. Note that changes from the results of Tables 2 to 4 occur in the intervals older than $6.4 \mathrm{Ma}$ and younger than $13 \mathrm{Ma}$. Note also that the correlation by Poore et al. (1984) of the first occurrence of the calcareous nannofossil Catinaster coalitus with Chron 9 (adjusted to Chron 11, this report) is rejected because Percival (1984) does no record C. coalitus at Site 519.

a Diatom (D), radiolarian (R), calcareous nannofossil (N), and planktonic foraminiferal (P) datum levels labeled as in Tables 2 to 5 . Additional datum levels not used in Tables 2 to 5 labeled with letters only.

B. = bottom; T. = top.

c Burckle (1978)

Theyer et al. (1978)

Haq et al. (1980).

Barron, unpublished data, Core RC-12-418.

8 Ciesielski (1983).

hyan et al, (1974).

Johnson and Wick (1982).

Poore et al. (1984).

Burckle et al, (1982).

1 Paleomagnetic correlations, Hole 575A (this chapter).

the last occurrence of $C$. japonica is near the top of a normally polarized interval (at about 10 to $4 \mathrm{~m}$ sub-bottom), which is either the top of Chron 11 or the lower normal event of Chron 10, according to the presence of N15 planktonic foraminifers. Johnson and Wick (1982) directly calibrate the last occurrence of $C$. japonica with the top of Chron 11 in seven piston cores from the tropical Pacific. Because $C$. japonica is a tropical radiolarian, is unlikely that it ranges higher at Site $512\left(50^{\circ} \mathrm{S}\right)$ than it does it the tropical Pacific. The same argument applies to N15 planktonic foraminifers. Consequently, correlation of the last occurrence of $C$. japonica with the upper part of Chron 11 at Site 512 is favored over correlation with lower Chron 10.

Ciesielski (1983) notes that R. D. Dallmeyer of the University of Georgia obtained a radiometric date of 8.7 $+0.2 \mathrm{Ma}$ on a ${ }^{40} \mathrm{Ar} /{ }^{39} \mathrm{Ar}$ analysis of a volcanic ash from Site 513 (Sample 513A-10-7, 10-13 cm), which lies at about the same latitude $\left(48^{\circ} \mathrm{S}\right)$ as Site 512 . This ash lies immediately above the last occurrence of $C$. japoni$c a$ in Section 1 of Core 513A-11 (Weaver, 1983; Ciesiel- ski, 1983). If the last occurrence of $C$. japonica is isochronous between Leg 71 Sites 512 and 513, these paleomagnetic and radiometric calibrations suggest that the top of Chron 11 should approximate $8.8 \mathrm{Ma}$. Because the dated top of Anomaly 5 is approximately $8.9 \mathrm{Ma}$ (Berggren et al., in press), an Anomaly 5-Chron 11 correlation is favored by these Leg 71 data.

Although there is a good argument for the Anomaly 5-Chron 11 correlation suggested by W. A. Berggren (pers. comm., 1984; and Berggren, Kent, and Van Couvering, in press), it seems premature (and impractical because of publication deadlines) to alter all the Leg 85 absolute-age estimates for the middle and late Miocene. The alternative biostratigraphic time scale (Fig. 14), ages for paleomagnetically calibrated middle and late Miocene microfossil datum levels (Table 8), and age-vs.-depth curves for Sites 572 to 574 (Fig. 15) presented in this addendum should serve the reader in adjusting the absolute ages derived from biostratigraphic and paleomagnetic correlations in the various Leg 85 chapters, should the Anomaly 5-Chron 11 correlation become widely accepted.

\section{ACKNOWLEDGMENTS}

Appreciation is due Fritz Theyer and Larry Mayer (the Co-Chiefs) and the entire crew for making Leg 85 a scientifically rewarding and enjoyable experience. This manuscript benefited from the reviews of David Bukry and Gerta Keller of the U.S. Geological Survey. David A. Johnson and W. A. Berggren of Woods Hole Oceanographic Institution were very helpful in explaining the basis for the alternative paleomagnetic correlations discussed in the Addendum. E.T.'s research was partially funded by NSF grant OCE 8310518 .

\section{REFERENCES}

Andrews, J. E., Packman, G., et al., 1975. Site 289. In Andrews, J. E., Packman, G., et al., Init. Repts. DSDP, 30: Washington (U.S. Govt. Printing Office), 231-398.

Backman, J., and Shackleton, N. J., 1983. Quantitative biochronology of Pliocene and early Pleistocene calcareous nannofossils from the Atlantic, Indian and Pacific oceans. Mar. Micropaleontol., 8: 141-170.

Barron, J. A., 1981. Middle Miocene diatom biostratigraphy of equatorial Pacific DSDP Hole 77B. Geosci. J., 2:137-144. 1983. Latest Oligocene through early middle Miocene diatom biostratigraphy of the eastern tropical Pacific. Mar. Micropaleontol., 7:487-515.

in press. Miocene to Quaternary planktic diatom biostratigraphy. In Bolli, H. M., and Saunders, J. B. (Eds.), Biostratigraphy by Marine Plankton: Cambridge (Cambridge University Press).

Barron, J. A., and Keller, G., 1982. Widespread Miocene deep-sea hiatuses: coincidence with periods of global cooling. Geology, 10: 577-581.

Barron, J. A., Keller, G., and Dunn, D. A., in press. A multiple microfossil biochronology for the Miocene. In Kennett, J. P. (Ed), The Miocene Ocean: Paleoceanography and Biogeography. Mem. Geol. Soc. Am. 163.

Berggren, W. A., 1969. Paleogene biostratigraphy and planktonic Foraminifera of northern Europe. In Brönnimann, P., and Renz, H. H. (Eds.), Proc. First Internat. Conf. Planktonic Microfossils: Leiden (Brill), 121-160.

1984. Correlation of Atlantic, Mediterranean, Indo-Pacific Neogene stratigraphics: geochronology and chronostratigraphy. In Ikebe, N., and Tsuchi, R. (Eds.), IGCP Project 114: Internat. Workshop Pacific Neogene Biostratigraphy (Osaka and Kobe, Japan, Nov. 24-29, 1981): Tokyo (Univ. Tokyo Press), pp. 93-110.

Berggren, W. A., Burckle, L. H., Cita, M. B., Cooke, H. B. S., Funnell, B. M., et al., 1980. Towards a Quaternary time scale. Quat. Res., 13:277-302.

Berggren, W. A., Kent, D. V., and Flynn, J. J., in press. Paleogene geochronology and chronostratigraphy. In Snelling, N. J. (Ed.), Geo- 
chronology and the Geologic Time Scale. Spec. Pap. Geol. Soc. London.

Berggren, W. A., Kent, D. V., and Van Couvering, J. A., in press. Neogene geochronology and chronostratigraphy. In Snelling, N. J. (Ed.), Geochronology and the Geologic Time Scale. Spec. Pap. Geol. Soc. London.

Berggren, W. A., and Van Couvering, J. A., 1974. The Late Neogene: biostratigraphy, geochronology, and paleoclimatology of the last 15 million years in marine and continental sequences. Palaeogeogr. Palaeoeclimatol. Palaeoecol., 16(1-2):1-216. 1978. Biochronology. In Glassner, G. V., and Hedberg, H. D. (Eds.), Contributions to the Geologic Time Scale. Stud. Geol. (Tulsa, Okla.), 6:39-55.

Blow, W. H., 1969. Late middle Eocene to Recent planktonic foraminiferal biostratigraphy. In Brönnimann, P., and Renz, H. H. (Eds.), Proc. First Internat. Conf. Planktonic Microfossils: Leiden (Brill), 199-422.

Bukry, D., 1972. Coccolith stratigraphy, Leg 9, DSDP. In Hays, J. D., et al., Init. Repts. DSDP, 9: Washington (U.S. Govt. Printing Office), 817-839.

1975. Coccolith and silicoflagellate stratigraphy, northwestern Pacific, Deep Sea Drilling Project Leg 32. In Larson, R. L. Moberly, R., et al., Init. Repts. DSDP, 32: Washington (U.S. Govt. Printing Office), 677-701.

1981. Synthesis of silicoflagellate stratigraphy for Maestrichtian to Quaternary marine sediment. Spec. Publ. Soc. Econ. Paleontol. Mineral., 32:433-444.

1983. Upper Cenozoic silicoflagellates from offshore Ecuador, Deep Sea Drilling Project Site 504. In Cann, J. R., Langseth, M. G., Honnorez, J., Von Herzen, R. P., White, S. M., et al., Init. Repts. DSDP, 69: Washington (U.S. Govt. Printing Office), 321-342.

Burckle, L. H., 1972. Late Cenozoic planktonic diatom zones from the eastern equatorial Pacific. Nova Hedwigia, 39:217-246. 1978. Early Miocene to Pliocene diatom datum levels for the equatorial Pacific. Proc. Second Working Group Meeting, Biostrat. Datum-Planes Pacific Neogene, IGCP Project 114 (Bandung, Indonesia, May 30-June 1, 1977). Spec. Publ. Geol. Res. Dev. Cent., 1:25-44.

Burckle, L. H., Keigwin, L. D., and Opdyke, N. D., 1982. Middle and late Miocene stable isotope stratigraphy: correlation to the paleomagnetic reversal record. Micropaleontology, 25(3):281-293.

Ciesielski, P. F., 1983. The Neogene and Quaternary diatom biostratigraphy of subantarctic sediments, Deep Sea Drilling Project Leg 71. In Ludwig, W. J., Krasheninnikov, V. A., et al., Init. Repts. $D S D P, 71$ : Washington (U.S. Govt. Printing Office), 635-665.

Foster, J. H., and Opdyke, N. D., 1970. Upper Miocene to Recent magnetic stratigraphy in deep-sea sediments. J. Geophys. Res., 75: 4464-4473.

Gartner, S., 1972. Coccolith age determinations, Leg 9, DSDP. In Hays, J. D., et al., Init. Repts. DSDP, 9: Washington (U.S. Govt. Printing Office), 833-840.

1973. Absolute chronology of late Neogene calcareous nannofossil succession in the equatorial Pacific. Geol. Soc. Am. Bull., 84:2021-2034.

Gartner, S., Chen, M. P., and Stanton, R. J., 1983. Late Neogene nannofossil biostratigraphy and paleoceanography of the northeastern Gulf of Mexico and adjacent areas. Mar. Micropaleontol., $8: 17-50$.

Goll, R. M., 1972. Radiolaria. In Hays, J. D., et al., Init. Repts. DSDP, 9: Washington (U.S. Govt. Printing Office), 947-1058.

1979. The Neogene evolution of Zygocircus, Neosemantis, and Callimitra: their bearing on nasselarian classification. Micropaleontology, 25(4):365-396.

Haq, B. U., Worsley, T. R., Burckle, L. M., Douglas, R. G., Keigwin, L. D., Jr., et al., 1980. Late Miocene marine carbon isotope shift and synchroneity of some phytoplanktonic biostratigraphic events. Geology, 8:427-431.

Harwood, D. M., 1982. Oligocene-Miocene diatom biostratigraphy from the equatorial to the Antarctic Pacific [Master's thesis]. Florida State University, Tallahassee.

Hays, J. D., Saito, T., Opdyke, N. D., and Burckle, L. H., 1969. Pliocene-Pleistocene sediments of the equatorial Pacific: their paleo- magnetic, biostratigraphic and climatic record. Geol. Soc. Am. Bull., 80:1481-1514.

Hays, J. D., and Shipboard Scientific Party, 1972. Site 77. In Hays, J. D., et al., Init. Repts. DSDP, 9: Washington (U.S. Govt. Printing Office), 43-208.

Hsü, K. J., LaBrecque, J. L., and Shipboard Scientific Party, 1984. Site 519. In Hsü, K. J., LaBrecque, J. L., et al., Init. Repts. DSDP, 73: Washington (U.S. Govt. Printing Office), $27-93$.

Jenkins, D. G., and Orr, W. N., 1972. Planktonic foraminiferal biostratigraphy of the eastern equatorial Pacific-DSDP Leg 9. In Hays, J. D., et al., Init. Repts. DSDP, 9: Washington (U.S. Govt. Printing Office), 1059-1193.

Johnson, D. A., and Wick, B. J., 1982. Precision of correlation of radiolarian datum levels in the middle Miocene equatorial Pacific. Micropaleontology, 28(1):1-30.

Keigwin, L. D., Jr., 1980. Paleoceanographic change at the Eocene/ Oligocene boundary. Nature, 287:722-725.

Keigwin, L. D., Jr., and Keller, G., 1984. Middle Oligocene cooling from equatorial Pacific DSDP Site 77B. Geology, 12(1):16-18.

Keller, G., 1980. Early to middle Miocene planktonic foraminifera datum levels of the equatorial and subtropical Pacific. Micropaleontology, 26:372-391.

1981. Miocene biochronology and paleoceanography of the North Pacific. Mar. Micropaleontol., 6:535-551.

1983a. Biochronology and paleoclimate implications of middle Eocene to Oligocene planktic foraminiferal faunas. Mar. Micropaleontol., 7:463-486.

1983b. Paleoclimatic analysis of middle Eocene through Oligocene planktic foraminiferal faunas. Palaeogeogr. Palaeoclimatol. Palaeoecol., 43:73-94.

Keller, G., and Barron, J. A., 1983. Paleoceanographic implications of Miocene deep-sea hiatuses. Geol. Soc. Am. Bull., 94:590-613.

Keller, G., Barron, J. A., and Burckle, L. H., 1982. Paleomagnetic, stable isotope, carbonate, and microfossil stratigraphies in upper Miocene sediments in the North Pacific Ocean. Mar. Micropaleontol., 7:327-357.

Kennett, J. P., Houtz, R. E., Andrews, P. B., et al., 1975. Cenozoic paleoceanography in the southwest Pacific Ocean, Antarctic glaciation, and the development of the circum-Antarctic current. In Kennett, J. P., Houtz, R. E., et al., Init. Repts. DSDP, 29: Washington (U.S. Govt. Printing Office), 1155-1169.

Koblentz-Mishke, O. J., Volkovinsky, V. V., and Kabanova, J. G., 1970. Plankton primary production of the world ocean. In Woosten, W. S. (Ed.), Scientific Exploration of the South Pacific: Washington (Natl. Acad. Sci.), pp. 183-193.

LaBrecque, J. L., Kent, D. V., and Cande, S. C., 1977. Revised magnetic polarity time scale for Late Cretaceous and Cenozoic time. Geology, 5:330-335.

Leinen, M. A., 1979. Biogenic silica accumulation in the central equatorial Pacific and its implications for Cenozoic paleoceanography. Geol. Soc. Am. Bull., 90:801-803.

Lohmann, G. P., and Carlson, J. J., 1981. Oceanographic significance of Pacific late Miocene calcareous nannoplankton. Mar. Micropaleontol., 6:553-579.

Lowrie, W., Alvarez, W., Napoleone, G., Perch-Nielsen, K., PremoliSilva, I., et al., 1982. Paleogene magnetic stratigraphy in Umbrian pelagic carbonate rocks: the Contessa sections, Gubbio. Geol. Soc. Am. Bull., 93:414-432.

Nigrini, C., 1971. Radiolarian zones in the Quaternary of the equatorial Pacific Ocean. In Funnell, B. M., and Riedel, W. R. (Eds.), Micropaleontology of Oceans: Cambridge (Cambridge University Press), pp. 443-461.

Okada, H., and Bukry, D., 1980. Supplementary modification and introduction of code numbers to the low-latitude coccolith biostratigraphic zonation (Bukry, 1973-1975). Mar. Micropaleontol., 5: 321-325.

Osborn, N. I., Ciesielski, P. F., and Ledbetter, M. T., 1983. Disconformities and paleoceanography in the southeast Indian Ocean during the past 5.4 million years. Geol. Soc. Am. Bull., 94:1345-1358.

Percival, S. F., Jr., 1984. Late Cretaceous to Pleistocene calcareous nannofossils from the South Atlantic, Deep Sea Drilling Project Leg 73. In Hsü, K. J., LaBrecque, J. L., et al., Init. Repts. DSDP, 73: Washington (U.S. Govt. Printing Office), 391-424. 


\section{J. A. BARRON ET AL.}

Poore, R. Z., Tauxe, L., Percival, S. F., Jr., LaBrecque, J. L., Wright, R., et al., 1983. Late Cretaceous-Cenozoic magnetostratigraphic and biostratigraphic correlations of the South Atlantic Ocean: DSDP Leg 73. Palaeogeogr. Palaeoclimatol. Palaeoecol., 42: 127-149.

1984. Late Cretaceous-Cenozoic magnetostratigraphic and biostratigraphic correlations for the South Atlantic Ocean, Deep Sea Drilling Project Leg 73. In Hsü, K. J., LaBrecque, J. L., et al., Init. Repts. DSDP, 73: Washington (U.S. Govt. Printing Office), 645-655.

Riedel, W. R., and Sanfilippo, A., 1978. Stratigraphy and evolution of tropical Cenozoic radiolarians. Micropaleontology, 24(1):61-96.

Ryan, W. B. F., Cita, M. B., Dreyfus-Rauson, M., Burckle, L. H., and Saito, T., 1974. A paleomagnetic assignment of Neogene stage boundaries and the development of isochronous datum planes between the Mediterranean, the Pacific, and Indian oceans in order to investigate the response of the world ocean to the Mediterranean "salinity crisis." Riv. Ital. Paleontol. Strat., 80:631-688.

Saito, T., Burckle, L. H., and Hays, J. D., 1975. Late Miocene to Pleistocene biostratigraphy of equatorial Pacific sediments. In Saito, T., and Burckle, L. (Eds.), Late Neogene Epoch Boundaries: New York (Am. Mus. Nat. History), pp. 226-244.

Savin, S. M., Douglas, R. G., Keller, G., Killingley, J. S., Shaughnessy, L., et al., 1981. Miocene benthic foraminiferal isotope records: a synthesis. Mar. Micropaleontol., 6:423-450.

Shaw, A. B., 1964. Time in Stratigraphy: New York (McGraw-Hill).

Tauxe, L., Tucker, P., Petersen, N. P., and LaBrecque, J. P., 1983. The magnetostratigraphy of Leg 73 sediments. Palaeogeogr. Palaeoclimatol. Palaeoecol., 42:65-90.

Theyer, F., and Hammond, S. R., 1974. Paleomagnetic polarity sequence and radiolarian zones, Brunhes to Epoch 20. Earth Planet. Sci. Lett., 22:307-319.

Theyer, F., Mato, C. Y., and Hammond, S. P., 1978. Paleomagnetic and geochronologic calibration of latest Oligocene to Pliocene radiolarian events, equatorial Pacific. Mar. Micropaleontol., 3: 377-395.

Tjalsma, R. C., and Lohman, G. P., 1983. Paleocene-Eocene bathyal and abyssal benthic foraminifera from the Atlantic Ocean. Micropaleontology Spec. Publ. 4.

Vail, P. R., and Hardenbol, J., 1979. Sea level changes during the Tertiary. Oceanus, 22(3):71-80.

van Andel, T. H., Heath, G. R., and Moore, T. C., Jr., 1975. Cenozoic history and paleoceanography of the central equatorial Pacific Ocean. Mem. Geol. Soc. Am., 143:1-134.

Weaver, F. M., 1983. Cenozoic radiolarians from the southwest Atlantic, Falkland Plateau region, Deep Sea Drilling Project Leg 71. In Ludwig, W. J., Krasheninnikov, V. A., et al., Init. Repts. DSDP, 71: Washington (U.S. Govt. Printing Office), 667-686.

Westberg, M. J., and Riedel, W. R., 1978. Accuracy of radiolarian correlations in the Pacific Miocene. Micropaleontology, 24:1-23.

Wyrtki, K., 1966. Oceanography of the eastern equatorial Pacific Ocean. In Barnes, H. (Ed.), Ann. Rev. Oceanog. Mar. Biol., 4: 33-68.

Date of Initial Receipt: 1 February 1984

Date of Acceptance: 22 March 1984

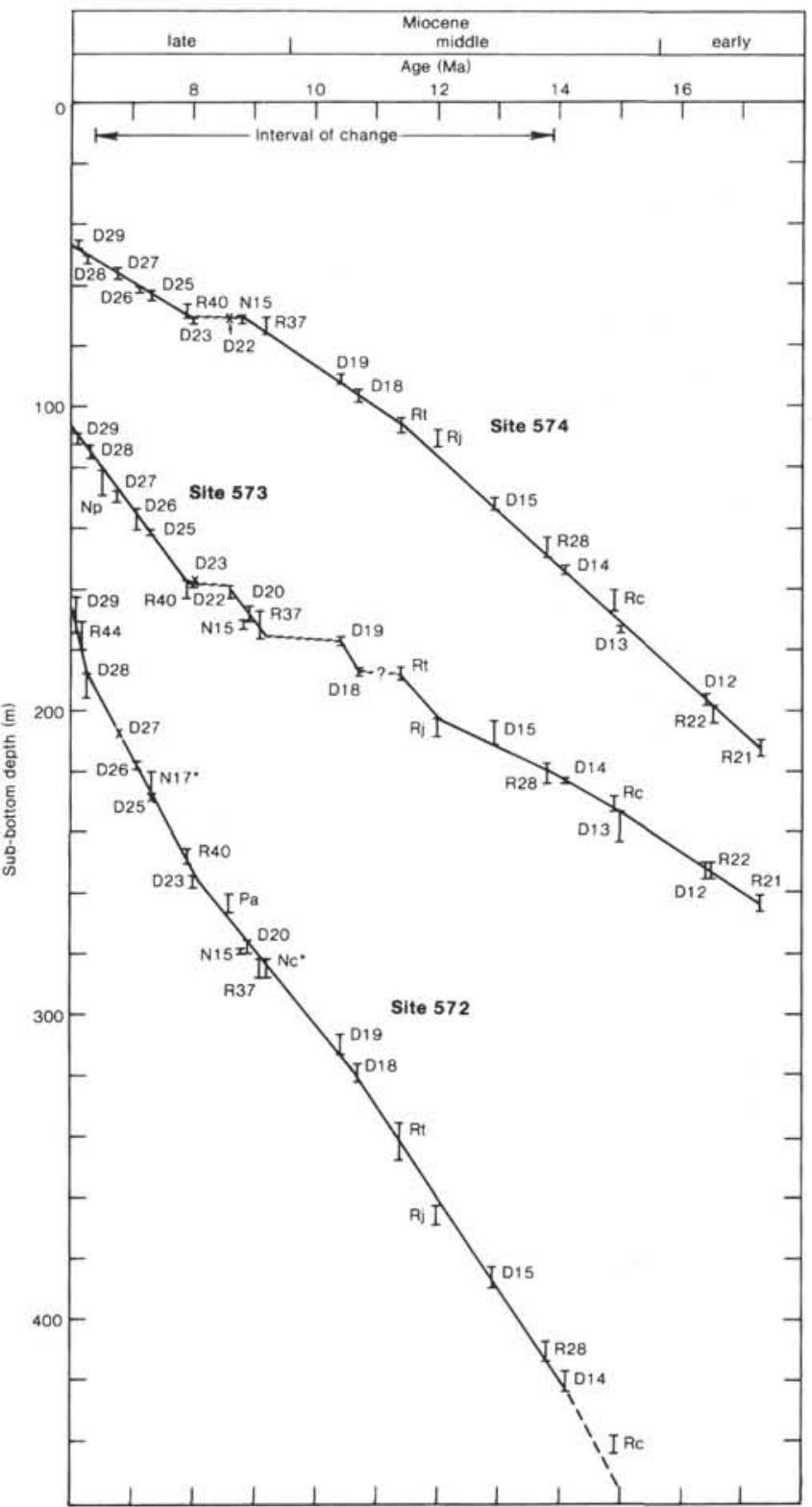

Figure 15. Age-vs.-depth plots for the middle and late Miocene at Sites 572,573 , and 574 , based on a correlation of paleomagnetic Anomaly 5 with paleomagnetic Chron 11 . See Table 8 for microfossil datum levels used to construct the plots. Asterisk denotes calcareous nannofossil datums after Gartner and Chow (this volume). 